\title{
Revisão do gênero Aglaoschema Napp (Coleoptera, Cerambycidae) ${ }^{1}$
}

\author{
Dilma Solange Napp ${ }^{2}$ \\ ${ }^{1}$ Contribuição número 1706 do Departamento de Zoologia, Universidade Federal do Paraná. \\ 2 Departamento de Zoologia, Universidade Federal do Paraná. Caixa Postal 19020, 81531-980 Curitiba, Paraná, Brasil. \\ Pesquisador do CNPq. E-mail: napp@ufpr.br
}

\begin{abstract}
Revision of the genus Aglaoschema Napp (Coleoptera, Cerambycidae). Aglaoschema Napp, 1994 and 17 species are redescribed. Aglaoschema viridipenne (Thomson, 1860) is revalidated and three new synonyms are proposed: Aglaoschema prasinipenne (Lucas, 1857) $=$ A. nigricorne $($ Bates, 1870) syn. nov. $=$ A. tibiale (Aurivillius, 1920) syn. nov., and Aglaoschema rufiventre (Germar, 1824) = A. erythrogaster (White, 1853) syn. nov. New species described: $A$. inca sp. nov. (Peru and Colombia), and A. apixara sp. nov. (Brazil). All the species are illustrated and a key is provided. KEY WORDS. Cerambycinae; Compsocerini; South America; taxonomy.
\end{abstract}

\begin{abstract}
RESUMO. Agloschema Napp, 1994 e 17 espécies são redescritos. Aglaoschema viridipenne (Thomson, 1860) é revalidada e três novos sinônimos são propostos: Aglaoschema prasinipenne (Lucas, 1857) $=$ A. nigricorne (Bates, 1870) syn. nov. $=$ A. tibiale (Aurivillius, 1920) syn. nov., e Aglaoschema rufiventre $(G e r m a r, 1824)=$ A. erythrogaster (White, 1853) syn. nov. Novas espécies descritas: $A$. inca sp. nov. (Peru e Colômbia), e A. apixara sp. nov. (Brasil). Chave para identificação e ilustrações de todas as espécies são fornecidas.

PALAVRAS-CHAVE. América do Sul; Cerambycinae; Compsocerini; taxonomia.
\end{abstract}

Aglaoschema foi proposto por NAPP (1994) para abrigar espécies até então incluídas em Orthostoma Lepeletier \& A.-Serville, 1830 (MonNé 1993) e que não eram congenéricas com Orthostoma abdominale (Gyllenhal, 1817), espécie-tipo do gênero.

Aglaoschema é exclusivamente sul-americano com 19 espécies distribuídas da Venezuela à Argentina (Monné 2005). Nesta primeira revisão do gênero são propostas três sinonímias, descrevem-se duas novas espécies e A. viridipenne (Thomson, 1860) é revalidada; assim o gênero permanece composto por 19 espécies. Destas, 11 têm distribuição predominante no leste do Brasil, cinco na região amazônica e duas no Brasil central; apenas $A$. basale (Melzer, 1933) e $A$. inca sp. nov. não estão registradas para o Brasil.

De acordo com Monné (2001), apenas quatro espécies de Aglaoschema têm registro de plantas hospedeiras: A. basale Acacia aroma e A. praecox, Mimosaceae; A. erythrocephala (Napp \& Martins, 1988) e A. ruficeps (Bates, 1870) - Acacia decurrens, Mimosaceae, e A. ventrale (Germar, 1824) - Enterolobium maximum, E. timbouvae, Mimosaceae, e Peltophorum vogelianum, Caesalpiniaceae. Os imaturos são desconhecidos.

Siglas arroladas no texto correspondem a: BMNH, The Natural History Museum, Londres; CUIC, Cornell University Insect Collection, Ithaca, Nova Iorque; DZUP, Departamento de Zoologia, Universidade Federal do Paraná, Curitiba; ISNB, Institut Royal des Sciences Naturelles de Belgique, Bruxelas; MACN, Museo Argentino de Ciencias Naturales "Bernardino Rivadavia", Buenos Aires; MNHN, Muséum National d'Histoire Naturelle, Paris; MNRJ, Museu Nacional, Universidade Federal do Rio de Janeiro, Rio de Janeiro; MZSP, Museu de Zoologia, Universidade de São Paulo, São Paulo; NHRS, Naturhistoriska Riksmuseet, Estocolmo; ZMUC, Zoological Museum, University of Copenhagen, Copenhague; ZSMC, Zoologische Staatssammlung des Bayerischen Staates, Munique.

Considerando a recente publicação de um catálogo (MonNé 2005), menciona-se sob cada táxon apenas a referência da descrição original e do catálogo, acrescidas de outras quando pertinentes. A seqüência das espécies no texto segue a da chave.

As dimensões são fornecidas em milímetros.

\section{Aglaoschema Napp, 1994}

Aglaoschema Napp, 1994: 658; Monné, 2005: 118.

Espécie-tipo: Orthoschema rufiventre Germar, 1824, por designação original.

Macho. Fronte transversa, declive. Tubérculos anteníferos arredondados, discretamente elevados. Olhos finamente granulados; lobos inferiores pouco desenvolvidos e pouco proeminentes, ligados aos superiores por estreita faixa de 2-3 omatídeos; lobos superiores estreitos, com cerca de um terço da largura dos inferiores, tão distantes entre si quanto o quádruplo da largura de um lobo. Genas tão a mais longas que a largura do lobo ocular inferior (exceto A. collorata). Mandíbulas (Figs 25-30) muito robustas, fortemente projetadas, acuminadas no ápice e freqüentemente deprimidas nas faces externa e dorsal; terço apical perpendicular ao eixo longitudinal (exceto A. mourei e A. ventrale). Palpos maxilares cerca de um terço mais longos que os labiais; artículos apicais de am- 
bos, cilíndricos e mais longos que os precedentes.

Antenas carenadas, ultrapassam o ápice elitral em 4,05,0 artículos (com raras exceções). Escapo clavado (estreitado em quase toda a metade basal, Fig. 8) ou piriforme (estreitado apenas na base, Fig. 5), com depressão basal (exceto A. collorata). Antenômeros III-XI subcilíndricos, um pouco deprimidos e pouco expandidos nos ápices. Na maioria das espécies, com espículos nos ápices internos dos III-V (os ápices externos inermes ou com espículos menores que os internos), os VI-X com espículos nos ápices interno e externo, estes mais desenvolvidos nos VII-IX. Antenômero III pouco mais longo que os V-IX, subiguais; IV e X pouco mais curtos; XI apendiculado, tão ou mais longo que o III (exceto A. haemorrhoidale, mais curto).

Protórax mais largo que longo, arredondado nos lados, tão ou quase tão largo quanto a largura umeral. Com pontuação sexual, variável na forma e extensão. Pronoto um pouco convexo, densamente microcorrugado. Cavidades coxais anteriores fortemente angulosas nos lados e abertas atrás. Processo prosternal estreito entre as procoxas, pouco e gradualmente atenuado para o ápice. Cavidades coxais médias abertas nos lados. Processo mesosternal aplanado, cerca de dois terços tão largo quanto a mesocoxa, subparalelo nos lados; margem apical emarginada acoplada à projeção anterior do metasterno, arredondada e tão larga quanto o ápice do processo mesosternal.

Élitros microcorrugados, opacos e pubescentes, cerca de 2,5-3,0 vezes a largura umeral e pouco convexos no dorso; lados paralelos até a curvatura apical. Extremidades variáveis.

Pro- e mesocoxas arredondadas, não proeminentes. Pernas curtas, as posteriores cerca de um terço mais longas que as anteriores. Fêmures lineares, os posteriores não alcançam o ápice elitral (exceto $A$. prasiniventre). Tíbias cilíndrico-deprimidas e carenadas (exceto A. mourei). Esporões tibiais curtos e subiguais. Tarsos curtos; metatarsômero I mais curto que II+III. Escovas tarsais compactas, sem linha central glabra.

Urosternito V emarginado no ápice, o VI parcialmente visível.

Fêmea. Mandíbulas mais delgadas e menos projetadas, arredondadas no terço apical e sem depressões. Antenas ultrapassam o ápice elitral em 1,5-3,0 artículos; antenômeros III-XI mais deprimidos, os VII-IX(X) até subserreados; freqüentemente com espículos mais manifestos do que nos machos; com pêlos muito longos e abundantes na face ventral dos III-VIII(IX); antenômero III o mais longo, os demais com comprimentos decrescentes, o XI mais curto que o III. Protórax até subanguloso nos lados; sem pontuação sexual. Urosternito V truncado-arredondado no ápice, o VI não visível.

Discussão. Aglaoschema é semelhante a Orthostoma Lepeletier \& A.-Serville, 1830, Compsocerus Lepeletier \& Serville, 1830 e Upindauara Napp \& Martins, 2006. Distingue-se de Orthostoma pela cabeça bem projetada à frente dos olhos com a fronte pouco inclinada; pelas mandíbulas com forte dimorfismo sexual, as dos machos muito robustas e projetadas; pelo escapo clavado ou piriforme com depressão basal; pelos fêmures lineares que não ultrapassam o ápice elitral e pelas tíbias carenadas. Em Orthostoma, a cabeça é pouco projetada à frente dos olhos com a fronte subvertical; as mandíbulas não têm dimorfismo sexual, as dos machos delgadas e não projetadas; o escapo é cilíndrico sem depressão na base; os fêmures são cilíndricos e robustos e, nos machos, ultrapassam o ápice elitral em cerca de um terço de seu comprimento e as tíbias não têm carenas. De Compsocerus, distingue-se, principalmente, por caracteres das antenas: 1) sem tufos de pêlos; 2) flagelômeros IV-X pouco mais curtos que o III com comprimentos subiguais; 3) flagelômero XI, nos machos, tão ou mais longo que o III; 4) pelo menos com espículos em todos os flagelômeros, exceto o XI. Em Compsocerus, o flagelômero VI apresenta denso tufo de pêlos [reduzido apenas nos machos de C. parviscopus (Burmeister, 1865)], os flagelômeros VII-X são evidentemente mais curtos que os precedentes, o XI é cerca de um quarto mais curto que o III e os flagelômeros são inermes, exceto no ápice externo dos VII-X nas fêmeas. Além disso, em Aglaoschema os élitros são opacos, densamente microcorrugados e pubescentes, enquanto em Compsocerus são brilhantes, mesmo nas espécies que apresentam pontuação mais fina e densa como em C. parviscopus e C. proximus Napp, 1977. De Upindauara, pelas genas tão longas quanto o lobo ocular inferior; pelos artículos apicais dos palpos maxilares e labiais cilíndricos; pelo escapo clavado ou piriforme; pelos ápices elitrais, no máximo, com espículo sutural; pelos fêmures cilíndricos e pelas tíbias carenadas. Em Upindauara as genas têm metade do comprimento do lobo ocular inferior; os artículos apicais dos palpos maxilares e labiais são securiformes; o escapo é cilídricoengrossado; os élitros têm espinho apical; os fêmures são fusiformes, comprimidos e as tíbias não têm carenas (NAPP \& MARTINS 2006). O padrão de colorido e o tegumento fortemente opaco de Upindauara bella, espécie-tipo, são bastante semelhantes aos de Aglaoschema mourei (Napp, 1993).

Várias espécies de Aglaoschema foram descritas com base em variações de colorido ou em fêmeas, o que ocasiona um certo grau de dificuldade no seu reconhecimento. O exame de quantidade razoável de material mostrou que o colorido pode variar ou não intra-especificamente; em algumas espécies a cor dos urosternitos, cabeça, prosterno e pernas é variável, enquanto em outras mantem-se constante; antenas com flagelômeros nitidamente bicolores (Figs 1-5) não variam, enquanto as unicolores apresentam variação na tonalidade dos flagelômeros, mas nunca são distintamente bicolores.

Os machos apresentam caracteres estruturais (principalmente mandíbulas, antenas e pontuação sexual) que permitem a distinção entre as espécies; já as fêmeas são muito uniformes e, não raro, o colorido é insuficiente para permitir sua identificação; algumas podem apresentar poucos caracteres morfológicos para auxiliar no reconhecimento. Observa-se, ainda, que, a exemplo do que ocorre em Compsocerus e em outros Compsocerini, machos de dimensões menores tendem a assemelhar-se às fêmeas com relação às antenas, mandíbulas e forma do protórax.

Revista Brasileira de Zoologia 24 (3): 793-816, setembro 2007 


\section{Chave para as espécies de Aglaoschema}

1. Antenômeros apicais com cor diferente dos basais (Figs 1-5).. 2

1 '. Antenômeros unicolores, pretos a castanhos, ou gradualmente escurecidos do III ao XI (Figs 6-24)

2. Antenômeros III-VII(VIII) pretos, os IX-XI esbranquiçados. Pernas pretas a castanhas, com ou sem brilho metálico (Figs $1,2)$

2'. Antenômeros III-VII(VIII) vermelho-alaranjados, os IX-XI pretos. Pernas vermelho-alaranjadas (Figs 3-5)

3. Protórax e mesosterno com colorido metálico verde ou azulescuro, usualmente concolor com os élitros (Fig. 1). Venezuela, Guiana Francesa, Brasil (Amazonas, Pará) Peru A. albicorne (Fabricius)

3 '. Protórax e mesosterno inteiramente vermelhos, às vezes com brilho metálico cúpreo (Fig. 2). Brasil (Amazonas, Rondônia), Peru A. cyaneum

4. Cabeça, protórax e esternos torácicos pretos a castanhoescuros, sem brilho metálico (Fig. 3). Brasil (São Paulo, Santa Catarina) A. violaceipenne

4'.Cabeça e esternos torácicos vermelho-alaranjados; pronoto vermelho-alaranjado ou com colorido metálico

5. Protórax bem arredondado nos lados, expandido no meio, inteiramente vermelho-alaranjado (Fig. 4). Brasil (Bahia, Minas Gerais, Espírito Santo ao Rio Grande do Sul) .........

A. viridipenne sp. reval.

5'. Protórax pouco arredondado nos lados, aspecto mais quadrangular. Pronoto com colorido metálico violáceo (Fig. 5). Brasil (Minas Gerais, Rio de Janeiro ao Rio Grande do Sul), Argentina .......... A. erythrocephala (Napp \& Martins)

6. Élitros com colorido metálico verde ou azul .................... 8 6'. Élitros com outro padrão de colorido ................................ 7

7. Élitros preto-violáceos, sem brilho metálico; protórax concolor com os élitros ou com brilho azulado-escuro; cabeça vermelho-sanguínea contrastante com o protórax. Escapo clavado; antenômero III sem carena. Mandíbulas do macho como na figura 28 (Fig. 6). Brasil (Bahia, Minas Gerais) ...

A. mourei

7'. Élitros amarelo-esverdeado-claros com as epipleuras e o quinto apical verde-metálico concolores com o protórax. Escapo piriforme; antenômero III carenado. Mandíbulas do macho como na figura 30 (Fig. 7). Brasil (Mato Grosso do Sul), Bolívia .............................................................. A. dulce

8. Escapo clavado (Figs 8-10, 12) com pontos finos, rasos e esparsos e mais longo que metade do comprimento do antenômero III; depressão basal alongada estende-se por toda a região estreitada. Fêmures com pontos finos e rasos; pontos setígeros pouco evidentes com cerdas esparsas ... 9

8'. Escapo subcilíndrico (Fig. 19) ou piriforme (Figs 13, 14), com pontuação densa a corrugada, até áspera, em toda a superfície, no máximo tão longo quanto metade do comprimento do antenômero III; depressão restrita à base ou ausente. Fêmures com pontos densos a corrugados; pontos setígeros ásperos com cerdas abundantes 12
9. Urosternitos vermelho-alaranjados …………................... 10

9'. Urosternitos com colorido metálico ................................ 11

10. Macho. Mandíbulas (Fig. 25), convexas na face dorsal, grosseiramente pontuado-rugosas. Antenômeros delgados, com cerdas moderadamente densas nos III-IV. Pontuação sexual formada por pontos grossos, densos e profundos, no prosterno e lados do protórax e do pronoto. Fêmures comprimidos nos ápices (Fig. 8). Colômbia, Peru

A. inca sp. nov.

10'. Macho. Mandíbulas (Fig. 26) amplamente deprimidas na face dorsal com duas carenas manifestas longitudinais. Antenômeros robustos, com densa franja curta e compacta na face inferior. Pontuação sexual formada por pontos finos e uniformes, mais aparentes no prosterno. Fêmures não comprimidos nos ápices (Fig. 9). Brasil (Bahia ao Rio Grande do Sul), Paraguai, Argentina .............................. A. ventrale

11. Antenômeros III-VI quase inermes, no máximo com espículo apical interno pouco conspícuo; o III nitidamente carenado e mais curto que o XI. Fêmures comprimidos no ápice, os posteriores não alcançam o ápice elitral. Extremidades elitrais subacuminadas, inermes (Figs 10, 11). Brasil (Pará)

A. tarnieri

11'. Antenômeros III-VI com espinhos internos desenvolvidos, o do III o mais longo; o III com carena pouco aparente e mais longo que o XI. Fêmures não comprimidos no ápice, os posteriores ultrapassam um pouco o ápice elitral nos machos. Extremidades elitrais arredondadas, o ângulo sutural projetado (Fig. 12). Brasil (Bahia, Espírito Santo) .

A. prasiniventre (Gounelle)

12. Protórax vermelho-alaranjado sem reflexos metálicos . 13

12'. Potórax com colorido metálico ...................................... 14

13. Urosternitos e base dos élitros vermelho-alaranjados. Mandíbulas do macho com pontos esparsos e não deprimidas nas faces dorsal e externa. Fêmea: antenômeros IX-XI não engrossados e com pilosidade esparsa (Fig. 13). Bolívia, Argentina . A. basale

13'. Urosternitos castanhos. Élitros unicolores, com colorido metálico da base ao ápice. Mandíbulas do macho grosseiramente pontuado-rugosas, deprimidas nas faces dorsal e externa. Fêmea: antenômeros IX-XI engrossados e com escova de pêlos (Figs 14, 15). Brasil (Bahia, Minas Gerais, Rio de Janeiro, Paraná, Santa Catarina) ..... A. prasinipenne

14. Cabeça e escapo vermelho-alaranjados (Protórax pouco expandido nos lados, aspecto quadrangular; face ventral do corpo com ou sem colorido metálico; fêmures mais freqüentemente avermelhados) (Fig. 18). Brasil (Minas Gerais, Rio de Janeiro) ................................................... A. ruficeps

14'. Cabeça, protórax e esternos torácicos com colorido metálico; escapo e fêmures negros a castanhos ............. 15

15. Fêmea. Escapo subcilíndrico, sem depressão basal. Genas com cerca da metade da largura do lobo ocular inferior. Cabeça e pronoto cúpreo-esverdeados; élitros verde-escuros. Antenômeros III-V subcilíndricos, delgados, o III cerca de 
um terço mais longo que os IV-V (Fig. 19). Brasil (Rondônia) A. collorata

15'. Macho e fêmea. Escapo piriforme com depressão basal. Genas tão longas quanto a largura do lobo ocular inferior. Cabeça e pronoto com colorido metálico verde ou azul-escuro, concolor ou pouco contrastante com o dos élitros ......... 16

16. Urosternitos, pelo menos os I-II, com colorido metálico17 16'. Urosternitos vermelho-alaranjados sem brilho metálico... 18

17. Urosternitos I-II verde-metálicos, os demais vermelho-alaranjados. Antenômero III não sulcado. Macho: pontuação sexual no prosterno, lados do protórax e do pronoto formada por pontos grossos, profundos e irregulares; protórax pouco expandido nos lados, cerca de um quarto mais largo que longo; élitros quase 4,0 vezes o comprimento do protórax (Fig. 20). Brasil (Bahia, Minas Gerais) .. A. apixara, sp. nov.

17'. Urosternitos azul-escuro-metálicos, os III-V, às vezes, castanhos no disco. Antenômero III sulcado. Macho: pontuação sexual restrita ao prosterno, formada por pontos finos e corrugados; protórax bem expandido nos lados, um terço mais largo que longo; élitros 3,0 vezes tão longos quanto o protórax (Fig. 21). Brasil (Mato Grosso, Goiás, Minas Gerais, São Paulo), Paraguai

A. concolor

18. Élitros sem pontos ásperos, os pontos setígeros pouco conspícuos. Macho: antenas atingem o ápice dos élitros no ápice do antenômero VI; XI mais longo que o III; pontuação sexual restrita ao prosterno e formada por pontos finos, quase inaparentes. Fêmures subglabros. Fêmea: antenômero XI mais longo que metade do III, arredondado no ápice (Fig. 22). Brasil (Goiás, Paraíba a Santa Catarina), Argentina A. rufiventre

18'. Élitros com pontos ásperos em toda a superfície. Macho: antenas atingem o ápice elitral no ápice do antenômero VII; XI mais curto que o III; pontuação sexual formada por pontos grossos, aparentes no prosterno, lados do protórax e do prosterno. Fêmures com pubescência densa. Fêmea: antenômero XI mais curto que metade do comprimento do III, aguçado no ápice (Fig. 24). Brasil (Minas Gerais, Espírito Santo, Rio de Janeiro, São Paulo), Argentina ........

A. haemorrhoidale

\section{Aglaoschema albicorne (Fabricius, 1801)}

Fig. 1

Cerambyx albicornis Fabricius, 1801: 269.

Orthoschema albicorne; Bates, 1870: 391.

Orthoschema (Orthostoma) albicorne; Prudhomme, 1906: 35.

Orthostoma albicorne; Monné, 1993: 21 (cat.).

Aglaoschema albicorne; Napp, 1994: 659; Monné, 2005: 118.

Macho. Colorido metálico verde ou azul-escuro; élitros concolores ou não com o protórax; em alguns exemplares a cabeça, protórax e metasterno com brilho violáceo. Antenas bicolores, os antenômeros I-VII(VIII) negros a castanhos, os IXXI esbranquiçados; escapo com brilho metálico.
Fronte brilhante com pontos esparsos. Vértice e região posterior da cabeça com pontuação densa a corrugada. Pubescência inaparente. Genas tão longas quanto a largura do lobo ocular inferior; ápices aguçados e divergentes. Mandíbulas como na figura 25: não angulosas no terço apical; face externa desenvolvida, com depressão moderada em quase todo o comprimento e pontos densos até corrugados; face dorsal com as margens laterais salientes e arredondadas. Escapo clavado, pouco mais longo que metade do comprimento do antenômero III; depressão basal rasa e alongada; pontos finos muito esparsos para a região apical, a pubescência quase nula; superfície subopaca. Antenômeros III$\mathrm{X}$ carenados nas faces dorsal, ventral e laterais, ligeiramente sulcados no dorso; subglabros com pubescência mais densa nos antenômeros com colorido esbranquiçado; III-IV(V) com pontuação mais corrugada, algo áspera no III, com pêlos anegrados moderadamente densos na face inferior; XI tão longo ou pouco mais curto que o III. Protórax com a maior largura logo após o meio; margem posterior mais larga que a anterior e, em alguns exemplares, com largura igual à pósmediana; lados pouco arredondados com os ângulos látero-posteriores projetados. Pronoto brilhante, densa e uniformemente microcorrugado, com pubescência acastanhada conspícua no disco. Prosterno, lados do protórax e do pronoto com pontuação sexual formada por pontos grossos, densos e profundos entremeados com pontos finos. Prosterno revestido com pubescência esbranquiçada. Mesoe metasterno subopacos revestidos com pubescência esbranquiçada curta e uniforme. Élitros com pontos setígeros ásperos em toda a superfície; extremidades freqüentemente com pequeno entalhe, o ângulo sutural projetado. Fêmures brilhantes com pontos finos, rasos e esparsos; pubescência quase nula e cerdas castanhas esparsas. Urosternitos subopacos com pubescência esbranquiçada curta e uniforme em toda a superfície.

Fêmea. Face lateral das mandíbulas com depressão rasa, as margens dorso-laterais não salientes. Depressão basal do escapo e carenas dos flagelômeros menos evidentes do que no macho, os flagelômeros não sulcados; pilosidade e pubescência mais densas; antenômeros IX-XI sem escova compacta de cerdas; XI cerca de um terço mais curto que o III. Lados do protórax mais sinuosos até projetados em tubérculo mediano discreto; maior largura na margem posterior com os ângulos laterais bem manifestos; pronoto com pontuação mais rasa e menos corrugada; lados do protórax brilhantes, com pontuação pubescente fina e não corrugada; prosterno com pontos finos e pubescência esparsa. Élitros com pontuação setígera mais evidente.

Dimensões, macho/fêmea respectivamente. Comprimento total 15,8-12,0/14,7-10,5; comprimento do protórax 2,7-2,0/ 2,5-1,7; maior largura do protórax 3,7-2,8/3,0-2,7; comprimento do élitro 11,3-8,8/10,5-7,7; largura umeral 3,8-2,8/3,3-2,5.

Material-tipo. De acordo com Zimsen (1964: 164) o holótipo macho está depositado no ZMUC e foi examinado por meio de diapositivo feito por J. S. Moure (DZUP). FabriciUs (1801: 269) indicou apenas "America meridional" como procedência.

Material examinado. Venezuela, Bolivar: El Domado, ma-

Revista Brasileira de Zoologia 24 (3): 793-816, setembro 2007 
cho, V.1965, A. Martinez leg. (MNRJ). Peru. Ica: Chanchamayo, fêmea, 5.III.1950, H. Zellibor leg. (MNRJ). Ucayalli: Pucallpa, macho, 20.III.1952, Zellibor leg. (MNRJ), fêmea (Rio Ucayalli, 200 m), I.1959, Dirings (MZSP). BRASIL. Amazonas: Benjamin Constant, macho, fêmea, II.1942, A. Parko leg. (MNRJ); Borba (Rio Madeira), macho, fêmea, IV.1943, B. Pohl leg., fêmea, VII.1943, Dirings leg. (MZSP); Itacoatiara, macho, I.1961, macho, IV.1964, Dirings leg. (MZSP); Mamoré, macho, VIII.1938, macho, IX.1941, A. Parko leg. (MNRJ); Manaus, fêmea, III.1959, C. Elias leg. (DZUP); Maués, macho, 7.XII.1936, Coll. Zellibor \& Hauff (MNRJ), fêmea, I.1937 (MZSP). Pará: Acará, fêmea, I.1978, P. Tadeu (MZSP); Altamira, macho, fêmea (Rio Xingu), I.1920 (MZSP); Itaituba (Rio Tapajós), 2 machos, 2 fêmeas, J. F. Zikán leg., fêmea, Dirings leg., 2 machos, II.1922, H.C. Boy, fêmea, II. 1930, B. Pohl leg., macho, V.1938, Guérin leg., 5 machos, 2 fêmeas, III.1926, macho, I. 1926, macho, IV.1926, 2 machos, V.1926 (MZSP), macho, fêmea, 1938 (MNRJ); Ponta Nova (Rio Xingu), macho, I.1920 (MZSP); Santarém (Taperinha), macho, V.1916, Hagmann leg. (MZSP); Xingu (município não informado), macho, J.F.Zikán leg. (MZSP), macho, J.F. Zikán leg. (MNRJ).

Monné (2005) registra a espécie, também, para a Guiana Francesa.

\section{Aglaoschema cyaneum (Pascoe, 1860)}

\section{Figs 2,25}

Orthostoma cyanea Pascoe, 1860: 62.

Orthoschema cyaneum; Lacordaire, 1869: 36.

Orthostoma cyaneum; Monné \& Giesbert, 1992: 251 (sin.). Aglaoschema cyaneum; Napp, 1994: 659; Monné, 2005: 119 (cat.). Orthoschema (Orthoschema) bicoloricorne Fuchs, 1959: 3.

Muito semelhante a A. albicorne, difere:

Cabeça vermelha ou com colorido metálico verde ou azulescuro. Antenas com escapo vermelho ou negro com brilho metálico. Protórax e mesosterno vermelhos, com ou sem reflexos metálicos violáceo-púrpura. Élitros subopacos, com colorido metálico verde, azul ou azul-violáceo. Metasterno e urosternitos com colorido metálico verde a azulado.

Cabeça com pontuação moderadamente fina, bem impressa e densa a corrugada. Protórax bem arredondado nos lados; sinuosidade látero-basal e ângulos látero-posteriores bem manifestos. Pronoto um pouco convexo com pubescência avermelhada aparente e pontuação fina, muito adensada e bem marcada, não corrugada. Pontos grossos aos lados do pronoto e protórax pouco contrastantes. Prosterno com pontos grossos e densos, bem mais aparentes que os dos lados do protórax. Élitros mais brilhantes, com colorido mais claro e mais largamente corrugados; pontuação setígera áspera bem evidente em toda a superfície.

Dimensões, macho/fêmea respectivamente. Comprimento total 16,8-13,0/15,3-11,7; comprimento do protórax 3,5-2,2/ 2,7-1,5; maior largura do protórax, 4,0-2,7/3,3-2,7; comprimento do élitro 12,2-9,5/11,5-8,7; largura umeral 4,2-2,8/3,7-2,8.

Material-tipo. De Orthostoma cyanea Pascoe, 1860: holóti- po fêmea (BMNH), descrito do Brasil, Pará, examinado. De Orthoschema (Orthoschema) bicoloricorne Fuchs, 1959: série sintípica, não examinada, composta de cinco machos e duas fêmeas provenientes do Peru, Loreto: Iquitos, e depositados no ISNB (Monné 2005).

Discussão. Fuchs (1959) ao descrever a espécie relacionou-a a A. albicorne e A. cyaneum, sem comentar as possíveis diferenças. Pela descrição original, a única diferença entre Orthoschema bicoloricorne e O. cyaneum seria a coloração da cabeça e do escapo, variáveis intra-específicamente. A sinonímia entre as duas espécies foi proposta por Monné \& GIESBERT (1992).

Material examinado. Peru. Loreto: Iquitos (San Roque), fêmea (MZSP). Brasil. Amazonas: 3 machos (MZSP); Benjamin Constant, (Rio Quichito) fêmea, XII.1942, A. Parko leg., macho, II.1957, I.C. Lima leg. (MNRJ), (Rio Javary, Alto Amazonas) fêmea, III.1961, fêmea, III.1962, 2 fêmeas, XII.1963, Dirings leg. (MZSP); São Paulo de Olivença, fêmea, III.1959, Dirings. leg. (MZSP); Tefé, 2 machos, fêmea, J. F. Zikán leg. (MZSP), macho, J. F. Zikán leg., macho I.1940, H. Zellibor leg. (MNRJ), macho, 2 fêmeas, XI.1958, 5 machos, 2 fêmeas, I.1959, Dirings leg. (MZSP), fêmea, XII.1961, F.M. Oliveira leg. (MNRJ). Rondônia: Porto Velho, 2 machos, fêmea, XI.1980, B. Silva leg. (MNRJ); Vilhena, macho, X. 1986, macho, XI.1986, C. Elias leg. (DZUP), fêmea, XI.1987, O. Roppa \& P. Magno leg. (MNRJ).

\section{Aglaoschema violaceipenne (Aurivillius, 1897)}

\section{Fig. 3}

Orthoschema violaceipenne Aurivillius, 1897: 244.

Orthostoma violaceipenne; Monné: 1993: 24 (cat.).

Aglaoschema violaceipenne; Napp, 1994: 659; Monné, 2005: 121 (cat.).

Macho. Cabeça, protórax, escutelo e face ventral do corpo negros a castanhos. Élitros com colorido metálico escuro, violáceo a azulado. Antenas bicolores, os antenômeros I-VII alaranjados, os VIII-XI negros a castanhos. Pernas alaranjadas.

Cabeça fina e densamente pontuada, com pubescência castanho-avermelhada pouco aparente. Mandíbulas como na figura 29: não angulosas no terço apical; face dorsal aplanada a deprimida, com pontos grossos e irregulares que, às vezes, formam rugas longitudinais irregulares; face lateral deprimida em toda a extensão. Escapo piriforme, pouco mais curto que metade do comprimento do antenômero III; depressão basal larga e manifesta; brilhante, com pontuação rasa e esparsa e pilosidade pouco aparente. Antenômeros III-VI(VII) subglabros, com pontuação áspera e raras cerdas avermelhadas na face inferior dos III-IV; VIII-XI com pubescência mais densa; XI desde subigual até pouco mais longo que o III. Protórax regularmente arredondado nos lados, a maior largura no meio; margens posterior e anterior com larguras subiguais, os ângulos látero-posteriores não projetados. Pronoto fina e densamente pontuado com pubescência vermelho-acastanhada mais aparente nos lados. Pontuação sexual formada por pontos finos e densos mais aparentes no prosterno que é revestido por densa pubescência 
esbranquiçada; lados do protórax com pontuação sexual pouco conspícua. Meso- e metasterno opacos, com pubescência esbranquiçada pouco aparente; metasterno com cerdas esparsas. Élitros com pontos setígeros mais aparentes para os ápices; extremidades arredondadas e inermes. Fêmures com pontuação fina, rasa e moderadamente densa; pubescência alaranjada pouco aparente e cerdas esparsas. Urosternitos brilhantes, subglabros.

Fêmea. Escapo com depressão menos acentuada e pubescência mais aparente; antenômeros III-XI pubescentes, sem pontuação áspera; cerdas na face inferior progressivamente mais densas para os distais formando escova compacta na face inferior dos IX-XI e metade apical do VIII (como na figura 4); IX-XI algo encurtados e engrossados, o XI pouco mais longo que metade do III. Protórax com discreta angulosidade no meio dos lados, os ângulos látero-posteriores um pouco projetados; prosterno com pontuação e pubescência esparsas.

Dimensões, macho/fêmea respectivamente. Comprimento total, 18,5-13,0/16,7-11,5; comprimento do protórax 3,5-2,5/ 3,0-2,2; maior largura do protórax 4,0-2,8/3,4-2,3; comprimento do élitro 13,3-9,0/12,0-8,3; largura umeral 4,3-3,2/3,8-2,7.

Variabilidade. Alguns exemplares procedentes do Estado de São Paulo podem apresentar o meso- e metasterno avermelhados.

Material-tipo. Holótipo fêmea do BrAsIL, Santa Catarina, depositado no NHRS, examinado por meio de diapositivos das faces dorsal e ventral do corpo.

Discussão. Aglaoschema violaceipenne, $A$. viridipenne e $A$. erythrocephala (Figs 3-5) são as três espécies do gênero que apresentam os flagelômeros III-VIII vermelho-alaranjados e os IX-XI negros a castanho-escuros. A. violaceipenne distingue-se das outras duas pelo colorido castanho a negro, quase unicolor do tegumento (contrastante com as pernas e antenas alaranjadas) e élitros também com colorido escuro, violáceo-metálico. De $A$. erythrocephala distingue-se, ainda, pelo pronoto sem colorido metálico, pelo protórax arredondado nos lados e pelas mandíbulas dos machos não angulosas no terço apical e com a face dorsal deprimida. Em A. erythrocephala (Fig. 5), o pronoto tem colorido metálico, o protórax é quadrangular e as mandíbulas dos machos (Fig. 30) têm dente rombo no terço apical e face dorsal convexa.

Material examinado. Brasil, São Paulo: Rio Claro, fêmea, XII.1970, F. Matthiesen leg. (MNRJ); São Paulo, (Cantareira) fêmea, XII.1954 (MNRJ), (Jabaquara) fêmea, XII.1946, (Saúde) macho, I.1916, macho, XI.1914, Melzer leg. (MZSP). Santa Catarina: Joinville, macho, I.1921, Schmith leg. (MZSP); Piçarras, 6 machos, X.1975, L. Pereira leg. (DZUP); São Bento, macho, XII.1969, H. Ebert leg., macho, 2 fêmeas, II.1972, macho, XII.1972, macho, III.1974, A. Maller leg., 6 machos, 2 fêmeas, II.1974, macho, III.1974, C. Rank leg. (DZUP); (Rio Vermelho), fêmea, XII.1948, macho, fêmea, I.1958, macho, III.1962, Dirings leg. (MZSP), fêmea XII.1966, A. Maller leg., macho, II.1972, M. Hummelgen leg., macho, III.1984, C. Rank leg. (DZUP); Tijucas do Sul, 2 machos, fêmea, XI.1975, L. Pereira leg. (DZUP).

\section{Aglaoschema viridipenne (Thomson, 1860), sp. reval.}

Figs 4, 29

Orthoschema viridipennis Thomson, 1860: 254.

Orthostoma viridipenne; Gemminger \& Harold, 1872: 2913 (cat.); Monné, 1993: 22 (sin.).

Orthoschema viridipenne; Aurivillius, 1910: 158; Napp, 1994: 659 (in syn.); Monné, 2005: 120 (cat.) (in syn.).

Orthoschema (Orthoschema) prasinipenne var. viridipenne; Gounelle, 1911:179.

Macho. Cabeça, protórax, escutelo, mesosterno, metasterno e pernas alaranjados. Antenas bicolores com o escapo, pedicelo e antenômeros III-VII alaranjados, contrastantes com os IX-XI castanhos a negros; base do escapo e metade apical do antenômero VIII, em alguns exemplares, anegrados. Élitros com colorido metálico verde, azul ou violáceo. Urosternitos castanho-escuros.

Cabeça fina e densamente pontuada, com pubescência avermelhada aparente. Mandíbulas (Fig. 29) como em A. violaceipenne; a depressão lateral, às vezes pouco manifesta. Escapo piriforme, pouco mais curto que metade do antenômero III; depressão basal larga e profunda; pontuação pubescente fina e pouco densa. Antenômeros III-XI subglabros com pubescência pouco mais densa para os distais, os III-V com pontuação áspera, os III-IV com algumas cerdas avermelhadas na face inferior; XI um quarto mais longo que o III. Antenômeros IX-X inermes. Protórax bem arredondado nos lados, a maior largura no meio, subigual à umeral; margens anterior e posterior com larguras subiguais, os ângulos látero-posteriores não projetados. Pronoto e lados do protórax com pontuação muito fina e densa, não microcorrugada, e pubescência avermelhada bem aparente. Prosterno com pontuação sexual formada por pontos finos e densos; pubescência esbranquiçada esparsa. Meso- e metasterno opacos, com pubescência pouco aparente. Élitros com pontos setígeros pouco contrastantes e esparsos, com cerdas curtas mais aparentes para os ápices; extremidades elitrais algo atenuadas e inermes. Fêmures com pontuação fina, rasa e moderadamente densa; pubescência alaranjada pouco aparente e cerdas esparsas. Urosternitos brilhantes, subglabros.

Fêmea (Fig. 4). Escapo com depressão basal rasa; antenômeros III-XI com pubescência densa e cerdas progressivamente densas e encurtadas para os distais, formando escova compacta na face inferior dos IX-XI e metade apical do VIII; IX-XI mais curtos e algo engrossados, o XI com metade do comprimento do III. Protórax, em alguns exemplares, projetado em tubérculo mediano arredondado e pouco manifesto, os ângulos látero-posteriores mais projetados do que no macho; prosteno com pontuação e pubescência esparsas.

Dimensões, macho/fêmea respectivamente. Comprimento total, 21,7-14,0/20,8-13,3; comprimento do protórax 4,3-2,7/ 4,0-2,7; maior largura do protórax 5,0-3,2/4,3-3,0; comprimento do élitro 15,2-10,0/15,3-9,8; largura umeral 5,3-3,5/5,0-3,3.

Material-tipo. Holótipo macho (MNHN), examinado. Thomson (1860: 254) indica apenas "Brasilia" como procedência.

Revista Brasileira de Zoologia 24 (3): 793-816, setembro 2007 
Discussão. Thomson (1860) ao descrever $A$. viridipenne ressaltou sua semelhança com $A$. prasinipenne (Lucas, 1857). GounelLe (1911: 179) considerou que a diferença no colorido das antenas entre as duas espécies poderia ser apenas uma variação intra-específica e tratou a espécie de Thomson como uma variedade de $A$. prasinipenne o que, provavelmente, levou os autores subseqüentes a incluir $A$. viridipenne (Thomson, 1860) na sinonímia de $A$. prasinipenne (Lucas, 1857). O exame de expressivo número de exemplares com ampla distribuição mostrou que o colorido das antenas permanece inalterado nas duas espécies, mesmo em áreas onde são simpátricas, o que embasa a presente revalidação de $A$. viridipenne. Vide outros comentários em A. prasinipenne (página 807).

Material examinado. Brasil, Bahia: Condeúba, macho, II.1976, S. Souza leg. (DZUP). Espírito Santo: Baixo Guandú, macho, XII.1970, C.T. \& C. Elias, macho, XII.1971, C. Elias (DZUP); Barra do São Francisco (Córrego do Itá), 4 machos, fêmea, XIXII.1956, W. Zikán leg. (MNRJ); Conceição da Barra, fêmea, IX.1968, C. Elias leg. (DZUP); Linhares, macho, XII.1964, 4 machos, XI.1965, fêmea, XI.1966, 4 machos, XII.1967, A. Maller leg., 2 machos, I.1973, C. Elias leg. (DZUP), 3 machos, 5 fêmeas (Parque Sooretama), XI.1967, F.M. Oliveira leg. (DZUP). Minas Gerais: Aimorés, fêmea, XII.1970, C. Elias leg. (DZUP); Cambuquira, 3 machos, XI.1968, 5 machos, XI.1969, H. Ebert leg. (DZUP); Poços de Caldas, macho, 2 fêmeas, XII.1976, M.A. Monné leg. (MNRJ). Rio de Janeiro: Rio de Janeiro (Corcovado), fêmea, XI.1960, C. A. Campos Seabra leg., fêmea. IX.1962, Alvarenga \& Seabra leg., fêmea, XII.1965, Moure \& Seabra leg. (DZUP), macho, 2 fêmeas, X.1975, macho, XI.1975, fêmea, X.1977, M. A. Monné \& C. A. Campos Seabra leg. (MNRJ). São Paulo: macho, X.1974, Dirings leg. (MZSP); São Paulo (Cantareira), macho, IX.1935, Werentzon leg., (Jabaquara) macho, XII.1945, fêmea, XII.1945, (Saúde) fêmea, XI.1914, fêmea, XII.1914, fêmea, I.1917, macho, XII.1918 (MZSP). Santa Catarina: Seara (Nova Teutônia), macho, XII.1949, fêmea, XI.1966, F. Plaumann leg. (DZUP). Rio Grande do Sul: Aratinga, 3 fêmeas, II.1964, Carbonell, Mesa \& Monné leg. (MNRJ); São Francisco de Paula, fêmea, II.1944 (DZUP); São Leopoldo, macho (DZUP).

\section{Aglaoschema erythrocephala (Napp \& Martins, 1988)} Figs 5, 30

Orthoschema (Orthoschema) erythrocephala Napp \& Martins, 1988: 484, fig. 4.

Orthostoma erythrocephala; Monné, 1993: 22 (cat.).

Aglaoschema erythrocephala; Napp, 1994: 659; Monné, 2005: 119 (cat.).

Macho. Cabeça, pernas e esternos torácicos vermelhoalaranjados. Antenas bicolores, com os antenômeros I-VII(VIII) vermelhos, os IX-XI castanho-escuros. Pronoto e élitros com colorido metálico verde, azul ou violáceo. Escutelo vermelhoalaranjado ou com colorido metálico. Urosternitos castanhoavermelhados.

Cabeça brilhante com pontuação fina e densa e pubes- cência castanho-avermelhada pouco aparente. Mandíbulas (Fig. 30) com dente rombo no terço apical; face dorsal convexa, com pontos moderadamente grossos, às vezes até confluentes; face externa com depressão em todo o comprimento. Escapo piriforme, com cerca da metade do comprimento do antenômero III; depressão basal bem marcada; opaco com pontuação densa, algo corrugada e áspera; pubescência e cerdas avermelhadas pouco conspícuas. Antenômeros III-V sulcados, com pontos finos, densos e ásperos e cerdas avermelhadas e abundantes na face inferior dos III-IV; a pubescência mais aparente para os antenômeros distais; XI tão ou pouco mais longo que o III. Protórax pouco expandido nos lados, com formato mais quadrangular; em alguns exemplares levemente projetado em tubérculo mediano arredondado; maior largura no meio; margens anterior e posterior com larguras subiguais, os ângulos látero-posteriores pouco ou não projetados. Pronoto brilhante, densamente microcorrugado, a pubescência pouco aparente. Lados do protórax menos corrugados com pontos finos pouco aparentes. Prosterno brilhante, subglabro, com pontuação sexual formada por pontos grossos, rasos, bem aparentes entremeados aos pontos finos e corrugados. Meso- e metasterno opacos com pubescência pouco aparente. Élitros com pontos setígeros não constrastantes e cerdas curtas, castanhas e mais aparentes para os ápices; extremidades arredondadas ou levemente entalhadas, projetadas ou não junto à sutura. Fêmures com pontos finos, rasos, moderadamente densos; pubescência avermelhada bem aparente e cerdas esparsas. Urosternitos brilhantes, subglabros.

Fêmea. Antenas ultrapassam o ápice elitral em um a dois artículos; escapo com depressão basal rasa; antenômeros IX-XI encurtados, com denso revestimento de cerdas curtas, negras e compactas, formando escova na face inferior (como na figura 4); XI cerca de um terço mais curto que o III. Prosterno com pontuação e pubescência muito esparsas, fraca e transversalmente microrrugoso.

Dimensões, macho/fêmea respectivamente. Comprimento total 14,5-11,7/14,1-11,7; comprimento do protórax 2,7-2,0/ 2,5-1,8; maior largura do protórax 3,0-2,2/2,7-2,2; comprimento do élitro 10,3-8,5/10,5-8,5; largura umeral 3,5-2,7/3,3-2,8.

Material-tipo. Examinados: holótipo macho do BRASIL, Paraná: Rolândia, X.1953, Dirings. leg. (DZUP). Parátipos. BRASIL. São Paulo: Amparo, 2 machos, fêmea, N. Andrade leg. (MZSP); Monte Alegre (Fazenda Santa Maria, 1100 m), macho, 2 fêmeas, XI.1942, F. Lane leg. (MZSP). Paraná: Caviuna, fêmea, XI.1943, A. Maller leg. (MZSP); Curitiba, macho, I.1938, Colégio Claretiano, fêmea, II.1938, C. Westernam leg. (MZSP), fêmea, XII.1946, F. Justus leg., macho (Acacia decurrens), XI.1967, Depto. Zool. leg., fêmea, X.1971, S. Laroca leg. (DZUP); Guarapuava, fêmea, I.1972, Mielke \& Tangerini leg. (DZUP); Ponta Grossa, fêmea, 1940, macho, XII.1943, F. Justus leg. (DZUP); Rolândia, fêmea, XI.1951, A. Maller leg. (DZUP). Santa Catarina: Seara (Nova Teutônia), macho, fêmea, XI.1955, fêmea, XI.1965, 2 machos, 2 fêmeas, XII.1965, macho, I.1966, macho II.1974, F. Plaumann leg. (DZUP). Rio Grande do Sul: Marcelino Ramos, fêmea, V.1939, 
macho, XII.1939 (MZSP); Santo Ângelo, 2 machos, I.1962, fêmea, XII.1970, O. Roppa leg. (MNRJ). Argentina. Misiones: Dos de Mayo, fêmea, XII.1951, Willink \& Monrós leg. (MNRJ).

Discussão. A. erytrocephala é muito semelhante a $A$. ruficeps (Fig. 18) e distingue-se: pelos flagelômeros bicolores; escapo opaco com pontuação densa, moderadamente profunda e áspera; antenômero XI tão a pouco mais longo que o III; antenas das fêmeas com os antenômeros IX-XI algo encurtados e com escova de pêlos na face inferior; pontuação sexual dos machos formada por pontos grossos restritos ao prosterno. Em $A$. ruficeps, os flagelômeros são unicolores, o escapo é brilhante com pontos finos e rasos, o antenômero XI é cerca de um quarto mais longo que o III, os antenômeros IX-XI das fêmeas não são encurtados e não têm escova de pêlos na face inferior e os machos apresentam pontos grossos irregularmente distribuídos e pouco aparentes aos lados do protórax e no prosterno.

\section{Aglaoschema mourei (Napp, 1993) Figs 6, 28}

Orthoschema (Orthoschema) mourei Napp, 1993: 655, fig. 2. Aglaoschema mourei; Napp, 1994: 659; Monné, 2005: 119 (cat.).

Macho. Tegumento fortemente opaco, negro-violáceo, sem reflexos metálicos. Cabeça vermelho-sanguínea contrastante com o colorido escuro do pronoto e élitros. Antenas e pernas negras. Face ventral do corpo concolor com os élitros ou castanho-escura com reflexos metálicos.

Cabeça opaca, finamente pontuado-corrugada, a pubescência inaparente. Mandíbulas (Fig. 28) bem projetadas, pouco e gradualmente curvas para o ápice; pontuação grossa e corrugada; face dorsal com depressão subvertical ampla e profunda, as margens superiores largas e arredondadas no terço basal; face externa com depressão bem marcada em todo o comprimento. Escapo clavado, mais longo que metade do comprimento do antenômero III; apenas deprimido na base; opaco, com pontuação fina e esparsa; pubescência inaparente e cerdas curtas muito esparsas. Antenômeros III-IV sem carena; III-V(VI) densamente pontuados, com cerdas anegradas na face inferior e com espinhos apicais internos, o do III mais notável; pubescência mais aparente para os antenômeros distais; XI tão longo quanto o III. Protórax pouco e regularmente arredondado nos lados, aspecto mais quadrangular, a maior largura no meio; largura da margem posterior pouco maior que a da anterior, os ângulos látero-posteriores pouco projetados. Pronoto fina e densamente pontuado-corrugado, a pubescência quase inaparente. Lados do protórax pubescentes, microcorrugados, com alguns pontos grossos pouco contrastantes. Prosterno com pontuação sexual formada por pontos grossos e densos; revestido por pubescência esbranquiçada e densa. Meso- e metasterno subopacos, revestidos por pubescência esbranquiçada. Élitros com pontos setígeros aparentes e cerdas semi-eretas em toda a superfície; extremidades arredondadas a levemente entalhadas, projetadas ou não junto à sutura. Fêmures brilhantes com pontos finos, rasos, moderadamente densos; pubescência esbran- quiçada e cerdas castanhas esparsas. Tíbias não carenadas. Urosternitos subopacos, revestidos com pubescência esbranquiçada.

Fêmea. Escapo sem depressão basal; antenômeros distais com pubescência e pilosidade abundantes; espinhos dos III-V menos evidentes do que no macho, os apicais externos dos VI$\mathrm{X}$ bem manifestos; IX-XI com densa pilosidade sem formar escova na face inferior; XI cerca de um terço mais curto que o III. Protórax com lados mais arredondados e ângulos látero-posteriores pouco pronunciados, ou com os lados um pouco divergentes para trás e os ângulos mais manifestos. Lados do protórax com pubescência densa, sem pontos grossos. Prosterno brilhante, subglabro, transversalmente microrrugoso. Tíbias carenadas.

Dimensões, macho/fêmea respectivamente. Comprimento total 14,3-13,3/14,2-13,7; comprimento do protórax 2,7-2,5/ 2,3-2,2; maior largura do protórax 3,2-3,0/2,9-2,8; comprimento do élitro 9,7-9,0/10,2-9,7; largura umeral 3,4-3,3/3,5-3,4.

Material-tipo. Holótipo macho do BrasiL, Bahia: Maracás, II.1963, F. M. Oliveira leg. (MNRJ). Parátipos. BrasiL: macho, 1862, Miniszech, (MNHN), fêmea (MZSP); Bahia: Condeúba, 2 machos, 2 fêmeas, 11.XII.1918, E. Gounelle leg. (MNHN); Maracás, macho, XI.1965, Oliveira \& Werner leg. (DZUP). Examinados o holótipo e dois parátipos (DZUP, MZSP).

Discussão. Distingue-se pelo tegumento fortemente opaco, preto-violáceo sem brilho metálico, contrastante com a cabeça vermelho-sanguínea, pelos antenômeros III-IV sem carena e o III com espinho apical interno desenvolvido. Os machos apresentam: mandíbulas (Fig. 28), únicas entre os Aglaoschema, fortemente projetadas, com a face dorsal ampla e fortemente deprimida e margem superior larga e arredondada no terço basal; protórax pouco arredondado nos lados, aspecto quadrangular e tíbias sem carena. As fêmeas são fácilmente reconhecíveis pelo colorido do tegumento e, ao contrário dos machos, têm tíbias carenadas.

Material examinado. Brasil. Bahia: Brumado, macho, fêmea, 17.IV.1976, C. Elias leg. (MNRJ); Caitité (13 km SE Maniaçu, 850 m), 5 machos, fêmea, 8-11.XII.2005, Mielke leg. (DZUP). Minas Gerais: Jaíba (Mocambinho), 5 machos, fêmea, III.1997, C. A. Julio leg. (MNRJ).

\section{Aglaoschema dulce (Napp \& Martins, 1988)}

\section{Fig. 7}

Orthoschema (Orthoschema) dulce Napp \& Martins, 1988: 483, fig. 2.

Orthostoma dulce; Monné, 1993: 22 (cat.).

Aglaoschema dulce; Napp, 1994: 659; Monné, 2005: 119 (cat.).

Macho. Cabeça, escapo, pedicelo, fêmures e esternos torácicos vermelho-alaranjados; fronte, vértice e lados do metasterno com discreto reflexo verde-metálico. Antenômeros III-XI, tíbias e tarsos negros a castanhos. Pronoto verde-metálico. Élitros amarelo-esverdeados no dorso, com as epipleuras e o quinto apical verde-metálicos concolores com o pronoto. Urosternitos verdemetálicos ou castanho-avermelhados com brilho metálico verde.

Cabeça brilhante, fina e densamente pontuado-corrugada, com pubescência avermelhada; genas com pontos ásperos. 

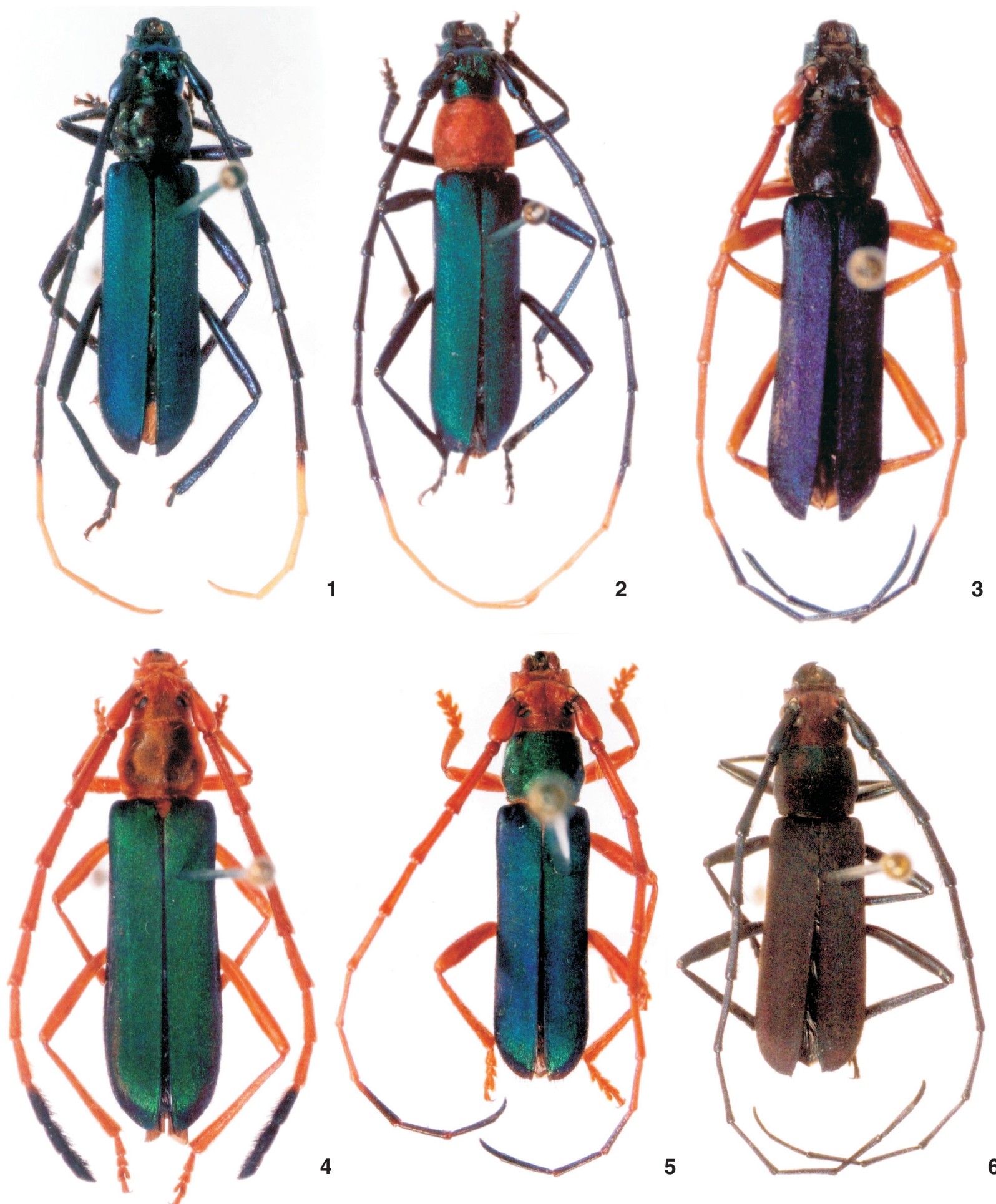

Figuras 1-6. (1) Aglaoschema albicorne, macho de Pucallpa, Peru, comprimento 10,5 mm; (2) A. cyaneum, macho de Tefé, Amazonas, comprimento 16,7 mm; (3) A. violaceipenne, macho de Piçarras, Santa Catarina, comprimento 13,3 mm; (4) A. viridipenne, fêmea do Rio de Janeiro, Rio de Janeiro, comprimento 16,0 mm; (5) A. erythrocephala, parátipo macho de Ponta Grossa, Paraná, comprimento 13,5 $\mathrm{mm}$; (6) A. mourei, macho de Jaíba, Minas Gerais, comprimento 13,5 mm. 
Mandíbulas como na figura 30: com dente rombo no terço apical; face dorsal convexa com pontos grossos moderadamente densos; face externa amplamente deprimida. Escapo piriforme, pouco mais curto que metade do comprimento do antenômero III; depressão basal bem impressa; opaco, com pontuação áspera mais adensada para a base e pubescência pouco aparente, com algumas cerdas curtas. Antenômeros III-XI com pontuação fina e adensada, áspera nos III-V; cerdas esparsas na face inferior do III, a pubescência mais adensada para os distais; XI cerca de um quinto mais longo que o III. Protórax regularmente arredondado nos lados, a maior largura no meio; margens posterior e anterior com larguras subiguais, os ângulos látero-posteriores não projetados. Pronoto e lados do protórax densamente microcorrugados, com pubescência bem aparente. Prosterno microcorrugado com pontos moderadamente finos, pouco aparentes, sem pontos grossos entremeados, e revestido por pubescência esbranquiçada densa. Meso- e metasterno subopacos e subglabros. Élitros revestidos com pubescência branca e sedosa; pontos setígeros pouco contrastantes em toda a superfície e cerdas curtas mais aparentes para os ápices; extremidades arredondadas, projetadas ou não junto à sutura. Fêmures com pontuação fina, rasa, moderadamente densa; pubescência esbranquiçada aparente e algumas cerdas avermelhadas. Urosternitos, nas regiões com colorido metálico, finamente corrugados e pubescentes.

Fêmea. Antenas com pubescência abundante; antenômeros IX-XI não encurtados e sem escova na face inferior; III quase inerme no ápice interno e cerca de um terço mais longo que o XI. Pronoto e lados do protórax menos corrugados do que no macho; prosterno com pontuação fina, rasa e pubescência esparsa.

Dimensões, macho/fêmea, respectivamente. Comprimento total 13,3/15,8-13,3; comprimento do protórax 2,5/2,8-2,5; maior largura do protórax $3,3 / 3,7-3,1$; comprimento do élitro 9,2/11,7-10,0; largura umeral 3,3/4,3-3,3.

Material-tipo. Holótipo fêmea (CUIC) e parátipo fêmea (MZSP), descritos do Brasil, Mato Grosso do Sul: Corumbá (Urucum), 23-29.XII (sem ano de coleta), Cornell Univ. Expedition, Lot 569. Examinado o parátipo.

Discussão. Distingue-se das demais espécies do gênero por ser a única em que os élitros são amarelo-esverdeados com as epipleuras e o quinto apical verde-claro-metálicos e densamente revestidos por pubescência esbranquiçada e sedosa. Além disso, a pontuação sexual dos machos é formada por pontos finos e pouco aparentes.

Material examinado. Bolívia, Santa Cruz: Florida, macho, I.1980 (MNRJ).

\section{Aglaoschema inca sp. nov.}

Fig. 8

Macho. Tegumento verde-metálico. Antenas e pernas negras a castanhas, o escapo e os fêmures com ou sem discreto brilho metálico. Urosternitos vermelho-alaranjados.

Cabeça densamente microcorrugada, a pubescência inaparente. Genas pontuado-rugosas, mais longas que a largura do lobo ocular inferior, divergentes no ápice. Mandíbulas como na figura 25; não angulosas no terço apical, subglabras, com pontos grossos e irregulares; face dorsal convexa, a lateral com ou sem depressão rasa na base. Escapo clavado, com cerca de três quartos do comprimento do III; depressão basal alongada; pontos moderadamente finos, esparsos e irregulares, mais densos e um pouco ásperos na região basal; pubescência pouco aparente, com algumas cerdas curtas na face inferior. Antenômeros III-IV(V) com pontuação fina, densa, um pouco áspera nos III-IV, com cerdas negras, moderadamente densas na face inferior; VI-XI subglabros, com raras cerdas na face inferior dos VI-VII; XI tão longo quanto o III. Protórax brilhante, um terço mais largo que longo, arredondado nos lados, a maior largura no meio; margem posterior cerca de um quarto mais larga que a anterior, os ângulos látero-posteriores um pouco projetados. Pronoto densamente microcorrugado com pubescência castanho-avermelhada pouco aparente. Prosterno, lados do protórax e do pronoto microcorrugados com pontuação sexual formada por pontos grossos, profundos e densos; prosterno e lados do protórax com pubescência esbranquiçada aparente. Meso- e metasterno opacos com pubescência esbranquiçada pouco aparente. Élitros sem pontos setígeros contrastantes, as cerdas mais conspícuas para os lados e ápices; extremidades um pouco atenuadas e inermes. Fêmures comprimidos nos ápices; brilhantes, com pontos finos, rasos e pubescência castanho-avermelhada, mais densos nos posteriores; pontos setígeros e cerdas, esparsos. Urosternito I e regiões laterais dos demais com pilosidade vermelho-alaranjada.

Dimensões, macho. Comprimento total 11,5-11,8; comprimento do protórax 2,0-2,3; maior largura do protórax 2,83,1; comprimento do élitro 8,3-8,5; largura umeral 3,2-3,3.

Material-tipo. Holótipo macho do Peru, Ucayalli: Pucallpa, 10.XI.1950, H. Zellibor leg. (MNRJ). Parátipo macho da ColôMBIA, Magdalena: Aracataca, 5.VIII.1920 ("in heavy forest with dense undergrowth") (DZUP).

Discussão. A. inca sp. nov. é semelhante a A. ventrale (Fig. 9) pelo colorido geral do corpo e forma do protórax. Distinguese pelos caracteres fornecidos na chave. Além disso, $A$. inca ocorre na Amazônia e $A$. ventrale tem distribuição no leste do Brasil.

Etimologia. O nome específico refere-se à civilização Inca.

\section{Aglaoschema ventrale (Germar, 1824)}

\section{Figs 9,26}

Callichroma ventrale Germar, 1824: 494.

Chrysoprasis ventralis; Audinet-Serville, 1834: 7.

Orthostoma ventrale; Germar in Guérin-Méneville, 1839:330.

Orthoschema ventrale; Aurivillius, 1910: 157.

Orthoschema (Orthoschema) ventrale; Gounelle, 1911: 177. Aglaoschema ventrale; Napp, 1994: 659; Monné, 2005: 121 (cat.).

Macho. Tegumento com colorido metálico verde a verde-azulado, opaco. Antenas e pernas negras a castanhas. Urosternitos vermelho-alaranjados.

Cabeça densamente microcorrugada, com pubescência castanho-avermelhada mais aparente no vértice. Genas com rugas 
transversais e pilosidade esparsa. Mandíbulas (Fig. 29) muito desenvolvidas e projetadas, com dente externo no terço apical; mais longas que o dobro do comprimento das genas; face dorsal amplamente deprimida e irregular, com duas carenas longitudinais manifestas; face externa larga na metade basal e bruscamente afilada na apical. Escapo clavado, com cerca de três quartos do comprimento do antenômero III; depressão rasa e alongada; pontuação fina e esparsa, a pubescência inaparente e raras cerdas curtas. Antenômeros III-XI algo engrossados com evidente franja curta e compacta de cerdas negras na face inferior, progressivamente encurtada para os antenômeros distais e entremeada com pêlos mais longos nos III-V(VI); III-V com pontuação densa, áspera e pubescência esparsa. Antenômero III, às vezes, com carena pouco manifesta; XI desde subigual até um quarto mais longo que o III. Protórax amplamente arredondado nos lados, a maior largura no meio; margens anterior e posterior com larguras subiguais, os ângulos látero-posteriores não projetados. Pronoto densamente microcorrugado com pubescência castanha aparente. Lados do protórax corrugados e pubescentes, com pontuação sexual fina e uniforme, menos aparente do que no prosterno. Prosterno opaco com área bem delimitada de pontos moderadamente finos, uniformemente distribuídos; revestido por pubescência esbranquiçada e densa. Meso- e metasterno subopacos, com pontos finos, esparsos e pouco conspícuos; com pubescência esbranquiçada mais aparente no disco do metasterno. Élitros com pontos setígeros inaparentes e cerdas curtas mais aparentes nas regiões laterais e apical; extremidades atenuadas em conjunto e inermes. Fêmures brilhantes, com pontos finos e rasos, mais densos nos posteriores; pubescência e cerdas castanhas esparsas, mais evidentes nos posteriores. Urosternitos brilhantes; o I e regiões laterais dos demais com pubescência alaranjada.

Fêmea. Mandíbulas menos desenvolvidas, cerca de um terço mais longas que as genas; face dorsal não deprimida, com ou sem carenas longitudinais. Antenas desde tão longas até 2,03,0 artículos mais longas que o corpo; escapo com depressão rasa e pontuação mais densa; franja de cerdas apenas na face inferior dos antenômeros III-IV, menos densa do que no macho; IX-XI não encurtados, o XI cerca de um quarto mais curto que o III. Protórax menos alargado do que no macho, com os lados mais sinuosos, às vezes projetados no meio; margem posterior mais larga que a anterior, os ângulos látero-posteriores um pouco projetados; lados do protórax e prosterno brilhantes, microcorrugados, com pubescência esparsa.

Dimensões, macho/fêmea respectivamente. Comprimento total 22,7-12,2/20,0-13,3; comprimento do protórax 4,5-2,2/ 3,3-2,3; maior largura do protórax 6,2-3,0/5,0-3,2; comprimento do élitro15,3-9,0/14,5-9,8; largura umeral 6,7-3,3/6,0-3,7.

Material-tipo. Não examinado. Germar (1824: 494) não forneceu informações sobre o número e o sexo dos exemplares examinados, embora, pela descrição original, teve exemplares de ambos os sexos, provenientes do Brasil sem outros detalhes de procedência. De acordo com MonNé (2005) o material-tipo está depositado no ZSMC.
Discussão. Aglaoschema ventrale distingue-se das demais espécies, principalmente, pelas mandíbulas do macho, únicas entre os Aglaoschema, e pelas antenas com franja compacta de pêlos na face inferior dos antenômeros III-XI (machos) ou IIIIV(V) (fêmeas). Nos dois sexos as mandíbulas são notavelmente projetadas, com o dobro do comprimento das genas (machos) ou um terço mais longas (fêmeas) e as genas são mais longas que o lobo ocular inferior e divergentes no ápice.

Material examinado. Brasil, Goiás: Rio Verde, 2 fêmeas, XII.1945 (MNRJ). Mato Grosso do Sul: Dourados, fêmea, I.1976, J. Lorenzoni leg. (DZUP). Bahia: Condeúba, 2 fêmeas, I.1976, fêmea, II.1976, S. Souza (DZUP); Encruzilhada (Estrada Rio-Bahia, km 965, Motel da Divisa, 960 m), fêmea, XI.1974, C.S. Carbonell leg. (MNRJ). Minas Gerais: Cambuquira, 12 machos, 4 fêmeas, XI.1968, 15 machos, 8 fêmeas, XI.1969, H. Ebert leg. (DZUP); Conceição da Aparecida (Fazenda São José), 2 machos, II.1960, J. C. M. Carvalho leg. (MNRJ); Coronel Pacheco, fêmea (MZSP); Poços de Caldas, macho, fêmea, XII.1976, M. A. Monné leg. (MNRJ). Espírito Santo: Baixo Guandú, 3 machos, 3 fêmeas, XII.1970, macho, I.1971, fêmea, XII.1975, C. Elias leg. (DZUP); Barra de São Francisco (Córrego do Itá), fêmea, XI.1956, W. Zikán leg. (MZSP), fêmea, XI-XII.1956, W. Zikán leg. (MNRJ), 4 fêmeas, XI.1957, A. Almeida leg. (DZUP); Colatina, 3 machos, III.1972, F. M. Oliveira leg. (MNRJ); Conceição da Barra, fêmea, XI.1968, C. Elias leg. (DZUP); Itapina, macho, fêmea, XII.1967, C. T. Elias leg. (DZUP), 2 machos, fêmea, Enoque leg. (DZUP); Linhares, macho, 4 fêmeas, IV.1965, macho, I.1967, macho, II.1967, macho, 2 fêmeas, XII.1967, A. Maller leg., 4 fêmeas (Parque Sooretama), XI.1967, F. M. Oliveira leg., fêmea, XII.1972, macho, I.1973, 2 machos, I. 1975, C. Elias leg., macho X.1976, Enoque leg. (DZUP); Santa Teresa, fêmea, XI.1964, C. Elias leg. (DZUP). Rio de Janeiro: Itatiaia (1100 m), fêmea, II.1969, Dirings. leg. (MZSP); Jacarepaguá, fêmea (Represa dos Ciganos), XII.1970, N. Santos (MNRJ), 3 machos, fêmea (Três Rios), XI.1964, D'Almeida leg. (DZUP); Rio de Janeiro, (Tijuca) fêmea (MZSP), (Represa Rio Grande), macho, X.1963, 7 machos, 9 fêmeas, XI.1966, macho, fêmea, XII.1966, F. M. Oliveira leg. (DZUP), macho, II.1978, B. Silva leg. (MNRJ). São Paulo: Araras, 2 fêmeas, K. Erbert leg. (DZUP); Avaré, macho, XI.1968, K. Erbert leg. (DZUP); Botucatu, macho, II.1969, A. Mantovan leg. (MZSP); Marília, macho, I.1951 (MZSP); São Carlos, 2 fêmeas, III.1975, M. M. Dias leg. (MZSP). Paraná: Foz do Iguaçu, 3 fêmeas, XII.1966, Exc. Dept. Zool. leg., macho, fêmea, II.1969, Moure \& Mielke leg., 2 machos, XI.1969, E. Chichovski leg. (DZUP); Jussara, fêmea, Exc. Dept. Zool. leg. (DZUP); Ortigueira, macho, I.1942, F. Justus leg. (DZUP); Rolândia, macho, fêmea, XII.1953, Dirings. leg. (MZSP); Tapejara, fêmea, I.1953, F. Justus leg. (DZUP); Terra Boa, macho, XII.1975, Exc. Depto. Zool. leg. (DZUP). Santa Catarina: Itapema, 2 machos, 2 fêmeas, I.1976, L. Pereira leg. (DZUP); Seara (Nova Teutônia), 2 machos, XI.1965, fêmea, XII.1965, macho, II.1966, macho, fêmea, XI.1966, F. Plaumann leg. (DZUP); Tijucas do Sul, macho, XI.1975, L. Pereira leg. (DZUP). ParaguaI. Alto Paraná: Itaquyry, 2 fêmeas, I.1980, Mielke \& Miers leg. (DZUP). 
Monné (2005) registra a espécie, também, para a Argentina (Misiones).

\section{Aglaoschema tarnieri (Bates, 1870) \\ Figs 10, 11, 27}

Orthoschema Tarnieri Bates, 1870: 392.

Orthostoma Tarnieri; Gemminger \& Harold, 1872: 2913 (cat.).

Orthostoma tarnieri; Monné, 1993: 23 (cat.).

Aglaoschema tarnieri; Napp, 1994: 659; Monné, 2005: 120 (cat.).

Macho. Colorido metálico verde a azul-violáceo no dorso; face ventral do corpo predominantemente verde-metálica, o disco do metasterno e dos urosternitos até castanhos. Antenas e pernas negras a castanhas; com ou sem brilho metálico no escapo e nos fêmures.

Cabeça brilhante, com pontuação fina e densa, até corrugada na região posterior. Genas rugosas, com pontos finos e esparsos, divergentes no ápice. Mandíbulas (Fig. 27) angulosas no terço apical; pontuação fina e esparsa e pilosidade pouco aparente; face externa desenvolvida com depressão larga e profunda em todo o comprimento; face dorsal deprimida com as margens laterais elevadas e arredondadas. Escapo clavado, quase tão longo quanto dois terços do comprimento do antenômero III; depressão basal ovalada e manifesta; subopaco, com pontuação fina e esparsa, a pilosidade pouco aparente. Antenômeros subinermes; III-IV(V) com pontuação fina, algo corrugada, e cerdas longas e abundantes na face ventral; VI-XI com pubescência esparsa; XI cerca de um quarto mais longo que o III. Protórax pouco arredondado nos lados, aspecto quadrangular, a maior largura no meio; margem posterior pouco mais larga que a anterior, os ângulos látero-posteriores não projetados. Pronoto brilhante, densamente microcorrugado, com pubescência pouco aparente. Prosterno, lados do protórax e do pronoto com pontuação sexual formada por pontos grossos, densos e profundos entremeados com pontos finos; prosterno revestido com pubescência esbranquiçada densa. A pontuação sexual grossa deixa uma calosidade longitudinal finamente pontuada, na metade anterior dos lados do protórax. Meso- e metasterno subopacos com pubescência esbranquiçada curta e uniforme em toda a superfície. Élitros com pontos setígeros pouco aparentes e esparsos e cerdas curtas pouco mais densas para os ápices; extremidades atenuadas em conjunto e inermes. Fêmures nitidamente comprimidos nos ápices, com pontuação fina, rasa, mais densa na metade basal; pubescência castanha aparente e cerdas curtas, esparsas. Urosternitos subopacos com pubescência esbranquiçada curta e uniforme em toda a superfície.

Fêmea (Fig. 11). Mandíbulas alongadas, regularmente arredondadas na face lateral que é aplanada ou ligeiramente deprimida na base. Escapo com depressão basal quase nula; antenômeros com pubescência e pilosidade densas notavelmente para os distais; IX-XI sem escova de cerdas; XI pouco mais longo que metade do comprimento do III. Lados do protórax mais sinuosos até projetados em tubérculo mediano discreto; maior largura na margem posterior com os ângulos laterais projetados; pronoto com pontuação mais rasa e menos corruga- da; lados do protórax brilhantes, com pontos finos, não corrugados; prosterno com pontos finos e pubescência esparsa. Élitros com pontuação setígera mais evidente.

Dimensões, macho/fêmea. Comprimento total 16,2-20,0/ 13,8-16,7; comprimento do protórax 3,2-4,0/2,3-2,9; maior largura do protórax 3,8-5,5/3,1-3,7; comprimento do élitro 14,3 / 10,2-10,5; largura umeral 5,5/3,5-4,2.

Material-tipo. Examinados dois síntipos fêmea procedentes do Brasil, Pará (MNHN). Um dos síntipos (Fig. 11) porta as etiquetas: 1) Orthoschema Tarnieri Bates; 2) Para, Ex. Museo H.W. Bates, 1892; Col. H.W. Bates, 1952; o outro, apenas a etiqueta de procedência.

Discussão. Aglaoschema tarnieri assemelha-se a A. prasiniventre (Fig. 12) pelo colorido geral do corpo e dos apêndices; forma e pontuação do escapo; mandíbulas, pontuação sexual e protórax quadrangular nos machos. A. tarnieri difere pelos antenômeros III-VI quase inermes, o III com carena conspícua, o XI cerca de um terço mais longo que o III; fêmures nítidamente comprimidos nos ápices, os posteriores não alcançam o ápice elitral; extremidades elitrais atenuadas em conjunto e inermes; protórax das fêmeas com a maior largura após o meio, os ângulos látero-posteriores pronunciados e a largura na margem posterior cerca de um terço maior do que na anterior. Em A. prasiniventre, os antenômeros III-VI têm espinhos apicais internos, o III com carena quase inconspícua e espinho interno desenvolvido, e o XI é mais curto que o III; os fêmures não são comprimidos nos ápices e os posteriores, nos machos, ultrapassam o ápice elitral; as extremidades elitrais são arredondadas e ligeiramente projetadas junto à sutura; o protórax das fêmeas tem a maior largura no meio, os ângulos látero-posteriores não são projetados e as margens anterior e posterior têm larguras subiguais. Além disso, até o momento, A. tarnieri está registrada apenas para a Amazônia, enquanto A. prasiniventre ocorre no leste do Brasil (Bahia e Espírito Santo), relacionada à Mata Atlântica.

Material examinado. Brasil, Pará: Belém (Utinga-Água Preta), macho, 25.II.1966, W. D. Edmonds (MZSP); Benevides, macho, II.1895, Gounelle leg. (MNHN, Coll. E. Gounelle).

\section{Aglaoschema prasiniventre (Gounelle, 1911)}

\section{Fig. 12}

Orthoschema (Orthoschema) prasiniventre Gounelle, 1911: 178. Orthostoma prasiniventre; Monné, 1993: 23 (cat.).

Aglaoschema prasiniventre; Napp, 1994: 659; Monné, 2005: 120 (cat.).

Macho. Colorido verde-metálico. Antenas e pernas negro-azuladas ou castanhas sem reflexos metálicos. Urosternitos inteiramente verde-metálicos ou castanhos no disco dos II-V.

Cabeça opaca, densamente microcorrugada, a pilosidade inaparente. Mandíbulas como em A. tarnieri (Fig. 27). Escapo clavado, mais longo que metade do comprimento do antenômero III; depressão basal manifesta; opaco, com pontuação fina, esparsa e pubescência inaparente. Antenômeros III-V com pontuação fina e algo corrugada, com algumas cerdas negras na face 

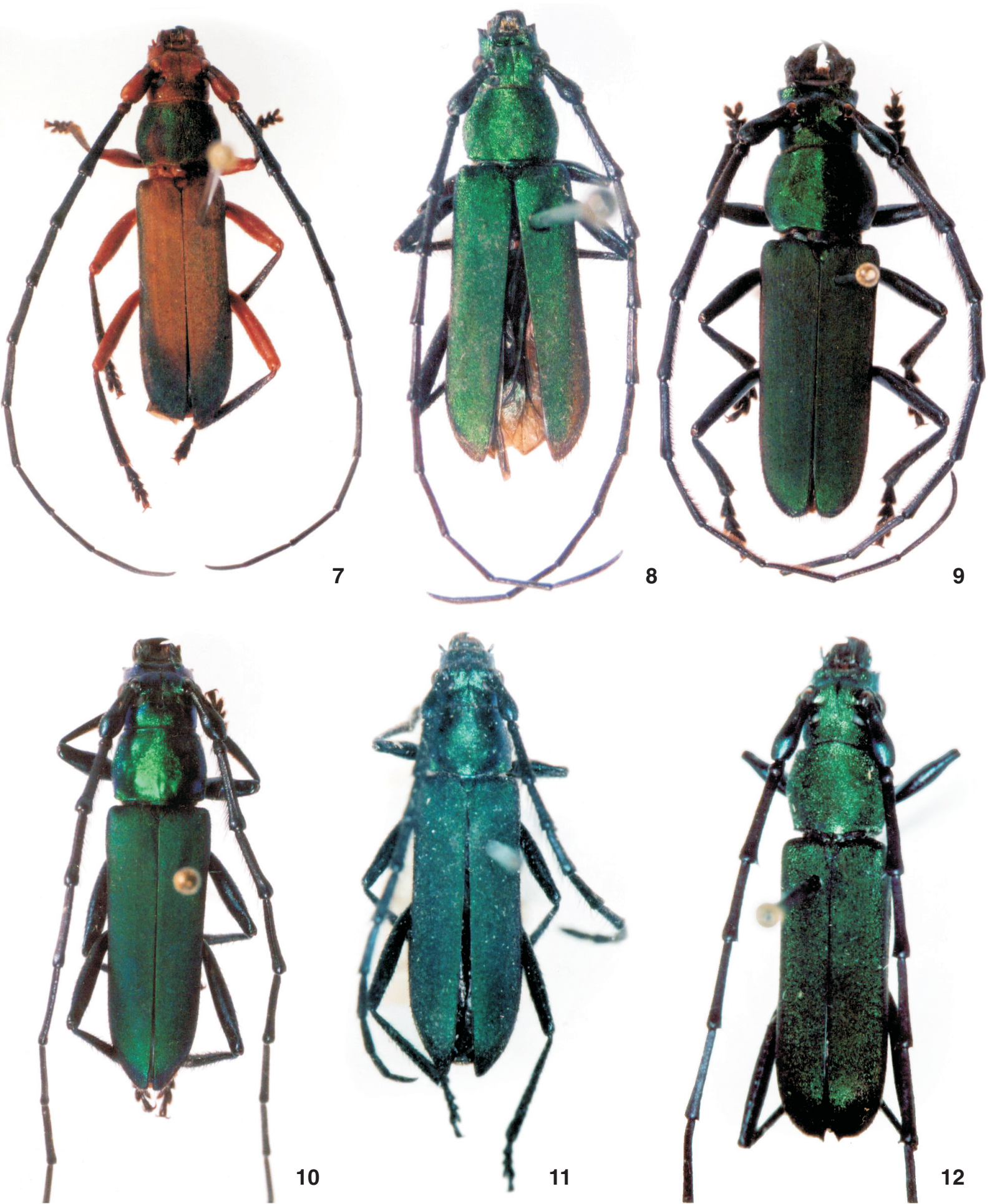

Figuras 7-12. (7) Aglaoschema dulce, macho de Florida, Bolívia, comprimento 13,3 mm; (8) A. inca sp. nov., holótipo macho, comprimento 11,7 mm; (9) A. ventrale, macho de Baixo Guandu, Espírito Santo, comprimento 20,6 mm; (10) A. tarnieri, macho de Belém, Pará, comprimento 16,3 mm; (11) Idem, holótipo fêmea (BMNH); (12) A. prasiniventre, síntipo macho (MNHN). Figuras 11 e 12 reproduzidas de diapositivos. 
inferior; VI-XI com pubescência esparsa; III com carena pouco manifesta e espinho apical interno bem aparente; XI mais curto que o III. Protórax pouco arredondado nos lados, aspecto quadrangular, a maior largura no meio; margem posterior pouco mais larga que a anterior, os ângulos látero-posteriores não projetados. Pronoto densamente microcorrugado, a pubescência inaparente. Lados do pronoto e do protórax pubescentes, com pontuação densa e áspera entremeada com pontos grossos e profundos. Prosterno com pontos grossos e densos, revestido com pubescência esbranquiçada densa. Meso- e metasterno com pubescência esbranquiçada esparsa; metasterno opaco com pontos finos e rasos no disco. Élitros com pontos setígeros esparsos em toda a superfície; extremidades arredondadas com o ângulo sutural projetado em espinho curto e largo. Fêmures com pontuação fina, rasa e pubescência esparsas; os posteriores ultrapassam ligeiramente o ápice elitral. Urosternitos brilhantes, com pontos finos e pubescência esbranquiçada mais densa no I e partes laterais dos demais; estes, no disco, com pontos finos, rasos e esparsos e algumas cerdas esbranquiçadas.

Fêmea. Escapo com depressão basal quase nula; antenômeros com pontuação e pubescência mais densas do que no macho; IX-XI não encurtados e sem escova compacta de cerdas na face ventral; XI pouco mais longo que a metade do comprimento do III. Lados do protórax mais arredondados, corrugados, sem pontos grossos. Prosterno fina e densamente pontuado, a pilosidade esparsa. Élitros com pontos setígeros mais evidentes do que no macho. Fêmures posteriores não atingem o ápice elitral.

Dimensões, macho/fêmea respectivamente. Comprimento total 13,4/10-8-12,3; comprimento do protórax 2,7/2,2-2,3; maior largura do protórax 3,3/2,7; comprimento do élitro 9,7/ 7,8-8,5; largura umeral 3,3/2,7-3,0.

Material-tipo. Série sintípica formada por dois machos e três fêmeas procedentes do BrasiL, Bahia e Espírito Santo, e depositados no MNHN. Foram examinados síntipos macho (Fig. 12) e fêmea provenientes, respectivamente, da Bahia e do Espírito Santo. O macho porta as etiquetas: 1) Orthoschema prasiniventre Goun.; 2) Bahia, Frunstorfer; e a fêmea, apenas a etiqueta de procedência: Espírito Santo, ex. Coll. Frunstorfer.

Material examinado. Brasil. Espírito Santo: Conceição da Barra, fêmea, 1-6.VII.1968, C. \& C.T. Elias leg. (DZUP).

\section{Aglaoschema basale (Melzer, 1933)}

\section{Fig. 13}

Orthoschema basale Melzer, 1933: 369

Orthostoma basale; Monné, 1993: 21 (cat.).

Aglaoschema basale; Napp, 1994: 659; Monné, 2005: 118 (cat.).

Macho. Tegumento vermelho-alaranjado. Antenômeros

III-XI castanho-escuros. Tíbias castanhas a vermelho-alaranjadas. Élitros com colorido metálico azul, violáceo ou verde, com a região basal vermelho-alaranjada concolor com o protórax; em alguns exemplares, com colorido metálico em toda a superfície.

Cabeça fina e densamente pontuada, algo corrugada, com pubescência amarelada pouco conspícua. Mandíbulas como na figura 30: com dente rombo no terço apical; face dorsal convexa com pontos moderadamente grossos; face lateral deprimida em toda a extensão. Escapo piriforme, com cerca da metade do comprimento do antenômero III; depressão basal larga e profunda; subopaco, com pontuação áspera pouco adensada e cerdas avermelhadas. Antenômeros III-V com pontuação áspera, moderadamente densa, os III-IV com cerdas castanhas na face inferior; XI até um quarto mais longo que o III. Protórax regularmente arredondado nos lados, a maior largura no meio, às vezes, subigual à largura umeral; margens anterior e posterior com larguras subiguais, os ângulos látero-posteriores não projetados. Pronoto muito fina, densa e uniformemente pontuado, às vezes com manchas irregulares e pouco aparentes de tegumento ou pubescência acastanhados. Lados do protórax fina e densamente pontuados. Prosterno subglabro, microcorrugado com pontuação sexual formada por pontos finos pouco aparentes. Meso- e metasterno brilhantes, subglabros, com pontos finos, rasos, mais aparentes nas regiões laterais do metasterno. Élitros com pubescência esbranquiçada bem aparente, os pontos setígeros quase inconspícuos com cerdas mais abundantes para os ápices; extremidades arredondadas, inermes ou projetadas junto à sutura. Fêmures com pontuaçãos fina, rasa, moderadamente densa; pubescência alaranjada aparente e cerdas mais abundantes na face inferior dos posteriores. Urosternitos brilhantes, subglabros.

Fêmea. Escapo com depressão basal rasa, com pontos densos e rasos, não ásperos; antenômeros III-XI com pontuação pubescente densa, sem asperosidades; IX-XI não engrossados e sem escova de pêlos; XI cerca de um quarto mais curto o III. Prosterno subglabro, com pontuação pubescente fina e superficial.

Dimensões, macho/fêmea respectivamente. Comprimento total 17,7-12,3/17,5-10,5; comprimento do protórax 3,3-2,3/ 3,0-1,9; maior largura do protórax 4,5-2,7/3,8-2,5; comprimento do élitro 12,2-8,3/12,7-7,8; largura umeral 4,7-3,0/4,5-3,0.

Material-tipo. Melzer (1933) baseou a descrição da espécie em dois machos e uma fêmea procedentes da Argentina, Jujuy: Ledesma, sem mencionar a instituição onde ficariam depositados. De acordo com MonNé (2005) os síntipos estariam depositados no MACN, embora BACHMANN \& Di IORIO (2002) não façam menção a essa espécie.

Discussão. Entre as espécies de Aglaoschema com antenas unicolores, A. basale assemelha-se a A. prasinipenne (Figs 14, 15) pelo colorido em geral, com a cabeça, escapo, protórax e esternos torácicos alaranjados. A. basale diferencia-se: élitros subopacos com pubescência esbranquiçada densa e região basal vermelho-alaranjada; urosternitos vermelho-alaranjados; mandíbulas do macho com dente rombo no terço apical e face dorsal convexa com pontos esparsos; escapo com pontos ásperos e densos em toda a superfície; antenômeros IX-XI das fêmeas não encurtados e com pilosidade esparsa. Em A. prasinipenne: élitros unicolores, fortemente opacos, com pubescência castanha pouco conspícua; urosternitos castanhos; mandíbulas dos 
machos como na figura 29, sem dente rombo, com a face dorsal aplanada a deprimida e grosseiramente pontuado-rugosa; escapo com pontos finos, rasos e esparsos; antenômeros IX-XI das fêmeas encurtados e com escova de pêlos (como na figura 4). Além disso, até o momento, A. basale está registrada apenas para a Bolívia e Argentina, enquanto A. prasinipenne tem ampla distribuição no leste do Brasil.

Material examinado. Bolívia, Santa Cruz: Mataral, macho, fêmea, II.1971, Martinez leg. (DZUP). Argentina. Tucumán: Las Cejas, 2 fêmeas (Malaise) (DZUP); Horco Molle, fêmea, XII.1968 (DZUP); Salta: macho, 2 fêmeas, II.1955, A. Willink leg. (MNRJ); Carapari, macho, I.1945, Bridarolli leg. (MZSP), macho, I.1945, Williner leg. (MNRJ); Coronel Moldes, macho, I.1945, F. Monrós leg. (DZUP), macho, II.1945, Monrós leg. (IMLA), fêmea, II.1944, Justus leg. (DZUP); San Martin (Pocitos), macho, XII.1971, Martinez leg. (DZUP); Urundel, macho, II.1945, Justus leg. (DZUP). Catamarca: San Antonio, fêmea, II.1958, Golbach leg. (DZUP). Jujuy, fêmea, Richter leg. (DZUP).

\section{Aglaoschema prasinipenne (Lucas, 1857)}

\section{Figs 14-17}

Orthostoma prasinipennis Lucas in Castelnau, 1857: 185, pr. 12, figs $2,2 \mathrm{a}-\mathrm{b}$.

Orthoschema prasinipenne; Lacordaire, 1869: 36.

Aglaoschema prasinipenne; Napp, 1994: 659; Monné, 2005: 120 (cat.). Orthoschema nigricorne Bates, 1870: 393. Syn. nov.

Orthostoma nigricorne; Gemminger \& Harold, 1872: 2913.

Aglaoschema nigricorne; Napp, 1994: 659; Monné, 2005: 119 (cat.). Orthoschema tibiale Aurivillius, 1920: 364. Syn. nov.

Orthostoma tibiale; Monné, 1993: 23 (cat.).

Aglaoschema tibiale; Napp, 1994: 659; Monné, 2005: 120 (cat.).

Macho (Figs 14-15). Cabeça, escapo (exceto a base, enegrecida), protórax e escutelo vermelho-alaranjados. Antenômeros III-XI negros a castanhos; pedicelo vermelho a negro. Pernas negras a castanhas, freqüentemente com os fêmures mais claros que as tíbias, até bicolores, com os fêmures vermelhos e as tíbias e tarsos negros a castanhos. Élitros com colorido metálico verde, azul ou violáceo. Meso- e metasterno vermelho-alaranjados a castanhos. Urosternitos castanhos a castanho-avermelhados.

Cabeça fina e densamente pontuada, com pubescência avermelhada aparente. Mandíbulas como na figura 29: sem dente rombo no ápice externo; face dorsal aplanada a deprimi$\mathrm{da}$, com pontuação grossa e irregular, às vezes formando rugas longitudinais irregulares; face externa com depressão em todo o comprimento, às vezes pouco evidente. Escapo piriforme, pouco mais curto que metade do comprimento do antenômero III; depressão basal larga e bem impressa; pontuação esparsa para o ápice, a pubescência esparsa. Antenômeros III-XI subglabros com pontuação áspera nos basais e pubescência mais evidente nos distais; face inferior dos III-IV com cerdas esparsas; XI cerca de um quarto mais longo que o III. Protórax arredondado nos lados, a maior largura no meio; margens anterior e posterior com larguras subiguais, os ângulos látero-posteriores pouco pronunciados; com pequena projeção lateral junto à margem anterior. Pronoto e lados do protórax fina e densamente pontuados, não microcorrugados, com pubescência avermelhada bem aparente e raras cerdas avermelhadas nas regiões laterais. Prosterno com pontuação sexual formada por pontos finos, revestido por pubescência esbranquiçada. Mesoe metasterno opacos com pubescência pouco aparente. Élitros com pubescência pouco aparente; pontos setígeros esparsos, não contrastantes, com cerdas curtas mais aparentes para as regiões laterais e ápices; extremidades arredondadas, não projetadas junto à sutura. Fêmures com pontuação fina, rasa, moderadamente densa; pubescência alaranjada aparente e cerdas esparsas. Urosternitos brilhantes, subglabros.

Fêmea (Figs 16-17). Mandíbulas aplanadas na face dorsal, com pontos grossos e densos. Antenas ultrapassam o ápice elitral em 1,5-2,0 artículos; depressão basal do escapo rasa; antenômeros III-XI com pubescência densa; IX-XI encurtados e com escova de cerdas na face inferior; XI pouco mais longo que metade do III. Protórax mais largo na margem posterior, os ângulos látero-posteriores mais projetados do que no macho; projeção látero-anterior mais evidente; prosterno com pubescência esparsa.

Dimensões, macho/fêmea respectivamente. Comprimento total 10,0-16,7/18,3-13,3; comprimento do protórax 4,2-3,0/ 3,5-2,2; maior largura do protórax 4,8-3,5/4,2-2,7; comprimento do élitro 14,0-11,7/14,8-9,8; largura umeral 5,2-4,0/5,0-3,2.

Material-tipo. De Orthostoma prasinipennis Lucas, 1857: em visita ao MNHN o autor localizou, na Colléction Génèrale, um macho e três fêmeas atribuídos a Orthostoma prasinipennis; o macho (Figs 14-15) corresponde perfeitamente à descrição e figuras apresentadas por LuCAS (1857) e porta as seguintes etiquetas: 1) Orthostoma prasinipennis; 2) 10.44; 3) Muséum Paris/ Rio 1844/ de Castelnau. Este exemplar pode ser o holótipo da espécie de Lucas, já que o autor, aparentemente, baseou sua descrição em único macho. As três fêmeas portam apenas as etiquetas 2 e 3 e têm antenas bicolores como em A. viridipenne (Thomson, 1860). De Orthoschema nigricorne: BATEs (1870) não informa o número de exemplares estudados; foram examinados dois síntipos fêmea (Fig. 16) (MNHN), um dos quais porta as etiquetas: 1) Minas Gerais; 2) Orthoschema nigricorne Bates; 3) Ex. Musaeum H.W. Bates, 1852; o outro exemplar porta as etiquetas 1 e 3. De Orthoschema tibiale Aurivillius, 1920: pelas dimensões dadas na descrição original, o autor teve em mãos mais de um exemplar, embora não mencione o número e o sexo dos mesmos e indique apenas "Brasilien" como procedência; de acordo com Monné (2005: 120) o material-tipo está depositado no NHRS. Examinado síntipo fêmea (NHRS) por meio de diapositivos (Fig. 17).

Discussão. O macho mencionado acima como provável holótipo de Orthostoma prasinipennis Lucas, 1857, apresenta os flagelômeros III-XI gradualmente escurecidos, de castanhoavermelhados até quase negros, os III-IV os mais claros, e per- 
nas bicolores com os fêmures alaranjados e as tíbias castanhas. Os síntipos examinados de Orthoschema nigricorne (Fig. 16), têm os flagelômeros e pernas negros, enquanto em Orthoschema tibiale os flagelômeros são negros e as pernas são bicolores (Fig. 17). Exemplares identificados como A. nigricorne pelo colorido das antenas, podem apresentar antenas desde negras até castanho-avermelhadas com os flagelômeros basais mais claros como em $A$. prasinipenne; da mesma forma, as pernas podem ser negras ou com os fêmures castanho-avermelhados. Auriviluius (1920: 364) expressou que Orthoschema tibiale poderia ser apenas uma forma de O. prasinipenne Lucas; o estudo de diapositivos das faces dorsal e ventral de um síntipo depositado no NHRS e de um exemplar do MNRJ comparado com o tipo (sic), mostrou que a única diferença com relação à espécie de Lucas é, também, o colorido das antenas. O exame de número considerável de exemplares mostrou que as diferenças entre as três espécies restringem-se ao colorido variável das pernas e antenas o que justifica a presente proposta de sinonímia, aliado ao fato de terem a mesma distribuição.

Esses fatores reforçam a revalidação de Aglaoschema viridipenne (Thomson, 1860), já que todos os exemplares examinados desta espécie têm antenas nitidamente bicolores e pernas invariavelmente vermelho-alaranjadas.

Material examinado. Brasil. Bahia: Ilhéus (São João - Água Preta), 2 machos, fêmea, IX-X. 1928, E. May, leg. (MZSP); Itapetinga, fêmea, 21.X.1974, C. Carbonell leg. (MNRJ); Rio Gongogy, macho, XII.1932, Camargo \& Andrade leg. (MZSP). Minas Gerais: Cambuquira, 4 machos, fêmea, XI.1969, H. Ebert leg. (DZUP); Juiz de Fora, 5 fêmeas, XI.1981, G. S. Andrade leg. (MNRJ); Mar de Hespanha, fêmea, I.1910, J. F. Zikán leg. (MZSP); Passa Quatro, fêmea, XI.1914, 2 machos, XI.1915 (MZSP). Rio de Janeiro: Nova Friburgo, (Mury, 1000 m) fêmea, fêmea, I.1967, D. Zajciw leg. (MNRJ), fêmea, XII.1974, J. H. Guimarães leg. (MZSP), fêmea, XII.1970, F. M. Oliveira leg. (MNRJ, comparado com tipo de Orthoschema tibiale Aurivillius). Paraná: Guarapuava, macho, I.1951, H. Schneider leg. (MZSP); Ponta Grossa, macho, XII.1938, Camargo leg. (MZSP). Santa Catarina: Seara (Nova Teutônia), macho, XII.1949 Col. F. Plaumann leg. (DZUP).

\section{Aglaoschema ruficeps (Bates, 1870)}

\section{Fig. 18}

Orthoschema ruficeps Bates, 1870: 393.

Orthostoma ruficeps; Gemminger \& Harold, 1872: 2913 (cat.). Aglaoschema ruficeps; Napp, 1994: 659; Monné, 2005: 120 (cat.).

Macho. Cabeça e esternos torácicos vermelhos, o prosterno, em alguns exemplares, com colorido metálico azul-violáceo. Escapo desde inteiramente negro a inteiramente vermelho-alaranjado ou negro na base; antenômeros III-XI negros a castanhos. Pronoto, escutelo e élitros com colorido metálico opaco azul a violáceo. Pernas negras ou bicolores, com os fêmures vermelhos e as tíbias e tarsos castanhos, ou inteiramente vermelhas. Urosternitos negros a castanhos.

Cabeça muito fina e densamente pontuada, com pubes- cência avermelhada a castanha pouco aparente. Mandíbulas como na figura 30: com dente rombo no terço apical; face dorsal convexa com pontos moderadamente grossos; face externa com depressão em todo o comprimento. Antenas ultrapassam o ápice elitral em 3,0-3,5 artículos. Escapo piriforme, pouco mais curto que metade do comprimento do antenômero III; depressão basal larga e bem impressa; brilhante, com pontuação pubescente fina e rasa. Antenômeros III-XI com pontuação pubescente fina, mais adensada para os distais, os III-V com cerdas castanhoavermelhadas abundantes na face inferior; XI cerca de um quarto mais longo que o III. Protórax pouco expandido nos lados, aspecto quadrangular, a maior largura no meio; margens anterior e posterior com larguras subiguais, os ângulos látero-posteriores não projetados. Pronoto densamente microcorrugado, com pubescência mais aparente para as regiões laterais. Lados do protórax microcorrugados e pubescentes com pontos maiores, irregularmente distribuídos e pouco aparentes. Prosterno com pontos finos e rasos entremeados com pontos maiores, pouco aparentes e revestido por pubescência esbranquiçada. Meso- e metasterno opacos com pubescência alaranjada moderadamente densa em toda a superfície. Élitros com pubescência pouco aparente; pontos setígeros não contrastantes, com cerdas curtas, negras e semi-eretas mais abundantes para as regiões laterais e ápices; extremidades arredondadas, não projetadas junto à sutura. Fêmures subopacos, com pontos finos, rasos e moderadamente densos, mais evidentes nos posteriores; pubescência aparente e cerdas castanhas esparsas. Urosternitos com pontuação pubescente mais densa no urosternito I e regiões laterais dos demais e com pilosidade esbranquiçada longa, bem aparente em todos os esternitos.

Fêmea. Escapo com depressão basal rasa; antenômeros III-XI com pubescência densa; IX-XI sem escova de cerdas; XI com cerca da metade do comprimento do III. Protórax tão longo quanto largo; margem posterior mais larga que a anterior; prosterno com pontos finos, rasos e pubescência esparsa.

Dimensões, macho/fêmea respectivamente. Comprimento total 19,0-15,2/13,7; comprimento do protórax 3,2-2,5/2,8; maior largura do protórax 3,8-2,8/2,8; comprimento do élitro 13,9-11,3/10,0; largura umeral 4,7-3,8/3,5.

Material-tipo. Bates (1870: 393) não indicou o número de exemplares estudados e mencionou apenas "Brasilia merid." como procedência. Foram examinados três machos e uma fêmea da Coleção Bates (MNHN). Um dos machos porta as estiquetas: 1) Rio de Janeiro; 2) Orthoschema ruficeps Bates; 3) Ex Musaeo H.W. Bates 1892. Este exemplar tem pronoto com pouco colorido metálico, o que estaria de acordo com a descrição original de Bates (1870): “...thorace infuscato...”. Outro macho porta as etiquetas 1 e 3 , e os restantes macho e fêmea têm etiqueta de procedência "S. Brasil" e a etiqueta 3. Nestes três exemplares o pronoto tem colorido metálico quase concolor com os élitros. Nos quatro exemplares o prosterno e as pernas são inteiramente vermelhos e as antenas são negras; os urosternitos são negros exceto os dois últimos, avermelhados. 

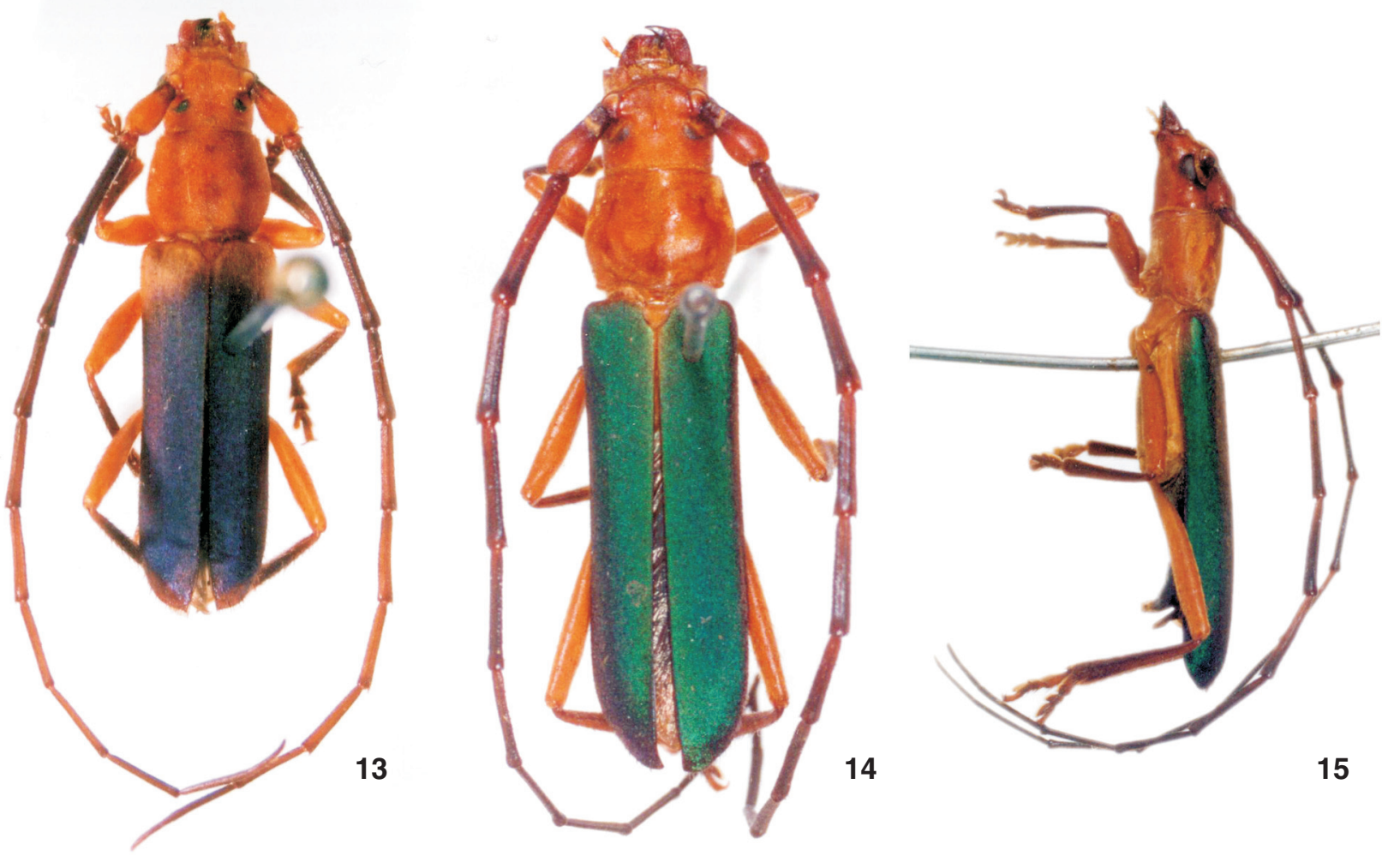

15
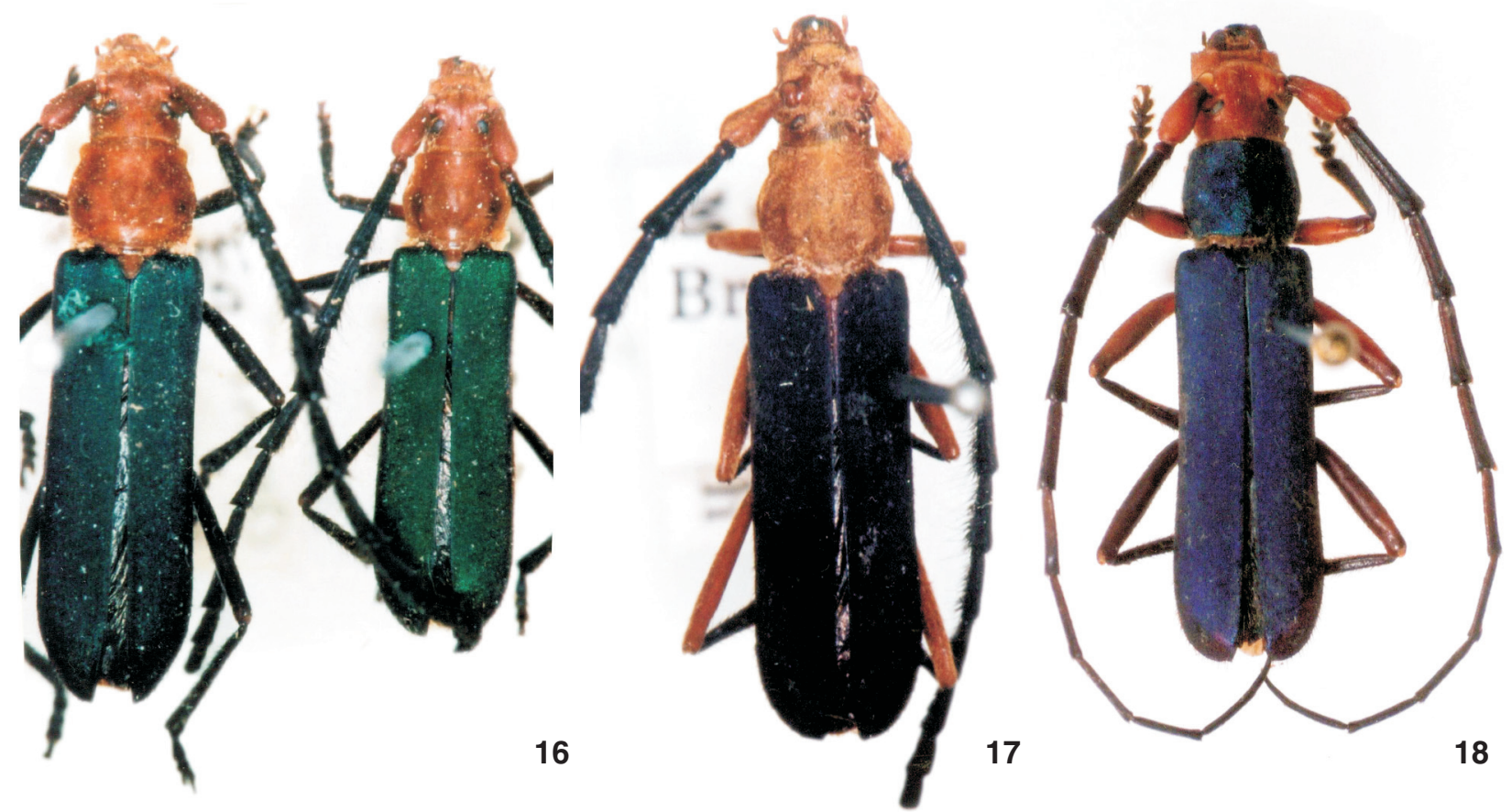

Figuras 13-18. (13) Aglaoschema basale, macho de Salta, Argentina, comprimento 11,7 mm; (14-15) A. prasinipenne, macho (MNHN), dorsal e lateral; (16) Orthoschema nigricorne, síntipo fêmea (MNHN); (17) O. tibiale, síntipo fêmea (NHRS); (18) Aglaoschema ruficeps, macho de Cambuquira, Minas Gerais, comprimento 14,7 mm. Figuras 16-17 reproduzidas de diapositivos. 
Discussão. Vide A. erythrocephala (página 800).

Material examinado. BRAsIL, Minas Gerais: Cambuquira, macho, fêmea, 7.XI.1968, 3 machos, XI.1969, H. Ebert leg. (DZUP). Rio de Janeiro: Nova Friburgo, fêmea, XII.1966, D. Zajciw leg. (MNRJ), fêmea, II.1975, J. H. Guimarães leg. (MZSP).

\section{Aglaoschema collorata (Napp, 1993)}

\section{Fig. 19}

Orthoschema (Orthoschema) collorata Napp, 1993: 653, fig. 1. Aglaoschema collorata; Napp, 1994: 659; Monné, 2005: 118 (cat.).

Fêmea. Tegumento com colorido metálico verde-dourado a acobreado na cabeça, acobreado no pronoto e lados do protórax, verde-claro nos esternos torácicos, verde-escuro a azulado nos élitros. Antenas e pernas negras. Urosternitos castanho-avermelhados ou o urosternito I e lados do II com colorido verde-metálico.

Cabeça densamente microcorrugada, a pubescência pouco aparente. Genas com cerca da metade da largura do lobo ocular inferior. Mandíbulas delgadas, arredondadas no terço apical, não deprimidas na face dorsal e sem depressão na face externa. Escapo subcilíndrico, pouco e gradualmente engrossado para o ápice, sem depressão basal; quase tão longo quanto metade do antenômero III; opaco, com pontuação fina, densa a corrugada, os pontos com microescultura; pubescência pouco aparente. Antenômeros III-V subcilíndricos, delgados, com pontuação fina, densa a corrugada, a pubescência mais aparente para os distais, com cerdas longas na face inferior dos III-VIII; IX-XI sem escova de cerdas; III-IV inermes; III cerca de um terço mais longo que os IV-V; os demais subiguais e decrescentes, os IX-XI não engrossados ou encurtados; XI com metade do comprimento do III. Protórax com lados divergentes da margem anterior até pouco além do meio onde são bem arredondados; margem posterior mais larga que a anterior, os ângulos látero-posteriores quase nulos. Pronoto e lados do protórax densamente microcorrugados e algo granulosos, a pubescência mais aparente nas regiões laterais. Prosterno finamente corrugado, com abundante pubescência esbranquiçada. Meso- e metasterno subopacos com pubescência esbranquiçada pouco aparente. Élitros com cerdas curtas mais abundantes para os ápices, os pontos setígeros não contrastantes; extremidades elitrais arredondadas, inermes. Fêmures cilíndricos e algo robustos, com pontuação densa e algo corrugada, com pubescência esbranquiçada e cerdas esparsas. Urosternitos microcorrugados, com pubescência esbranquiçada abundante nas regiões com colorido metálico; restante da superfície com pontuação e pilosidade esparsas.

Dimensões, fêmea. Comprimento total 10,7-9,8; comprimento do protórax 2,0-1,7; maior largura do protórax 2,4-2,3; comprimento do élitro 7,3-6,8; largura umeral 2,8-2,7.

Material-tipo. Examinados: holótipo fêmea (MNRJ) do Brasil, Rondônia: Ouro Preto do Oeste, X.1983, O. Roppa, J. Becker \& B. Silva leg.e parátipo fêmea (DZUP), com os mesmos dados do holótipo, exceto XI.1983.

Discussão. Aglaoschema collorata distingue-se das demais espécies por: padrão de colorido do corpo; genas com cerca da metade do comprimento do lobo ocular inferior; escapo subcilíndrico sem depressão basal; protórax com lados divergentes para trás até pouco além do meio onde se situa a maior largura. Os fêmures, robustos e cilíndricos, assemelham-se aos das espécies de Orthostoma. Até o momento, os únicos exemplares conhecidos de A. collorata são o holótipo e parátipo, ambos fêmeas.

\section{Aglaoschema apixara sp. nov.}

Fig. 20

Macho. Tegumento verde-metálico. Antenas e pernas negras, o escapo e fêmures com ou sem discreto brilho metálico. Urosternitos I-II verde-metálicos concolores com o metasterno; os III-V vermelho-alaranjados.

Cabeça brilhante, fina e densamente pontuada a corrugada, pilosidade inaparente. Mandíbulas sem dente rombo no terço apical; pontuação fina e esparsa ou com pontos maiores e mais densos; face dorsal convexa, a lateral sem depressão. Escapo piriforme, com cerca da metade do comprimento do antenômero III; depressão basal manifesta; subopaco com pontos finos, densos a corrugados, um pouco ásperos, em toda a superfície; pubescência inaparente e raras cerdas castanhas, curtas. Antenômeros não sulcados, brilhantes, com pubescência pouco aparente; III-V(VI) com pontos moderadamente densos e ásperos, os demais com pontuação fina e rasa; VII-IX com espinhos apicais externos desenvolvidos; XI cerca de um quarto mais longo que o III. Protórax pouco mais largo que longo, arredondado nos lados, a maior largura no meiro; margens anterior e posterior com larguras subiguais, os ângulos láteroposteriores não projetados. Pronoto densamente microcorrugado com pilosidade castanha quase inaparente. Prosterno, lados do protórax e do pronoto brilhantes, menos corrugados do que o pronoto, com pontuação sexual formada por pontos grossos, irregulares, mais aparentes e profundos no prosterno; este com pubescência esbranquiçada. Meso- e metasterno opacos, com pubescência esbranquiçada uniforme em toda a superfície e alguns pêlos longos, esbranquiçados. Élitros com pontos setígeros e cerdas mais aparentes para os ápices e regiões laterais; extremidades um pouco atenuadas, projetadas ou não junto à sutura. Fêmures subopacos, com pontuação fina, rasa e densa; pubescência esbranquiçada densa, com pontos setígeros contrastantes e cerdas castanhas, esparsos. Urosternitos com colorido metálico subopacos, microcorrugados com pubescência esbranquiçada aparente; os restantes, lisos, subglabros.

Fêmea. Escapo com depressão basal mais rasa do que no macho; antenômeros III-X brilhantes, a pubescência mais aparente para os distais; IX-XI não encurtados e sem escova de cerdas; XI pouco mais longo que metade do III. Protórax mais transverso e mais projetado no meio; margem posterior pouco mais larga que a anterior, os ângulos látero-posteriores ligeiramente projetados; prosterno, lados do protórax e do pronoto brilhantes, microcorrugados, sem pontos grossos; pubescência esparsa.

Dimensões, macho/fêmea. Comprimento total 9,5-12,5/

Revista Brasileira de Zoologia 24 (3): 793-816, setembro 2007 

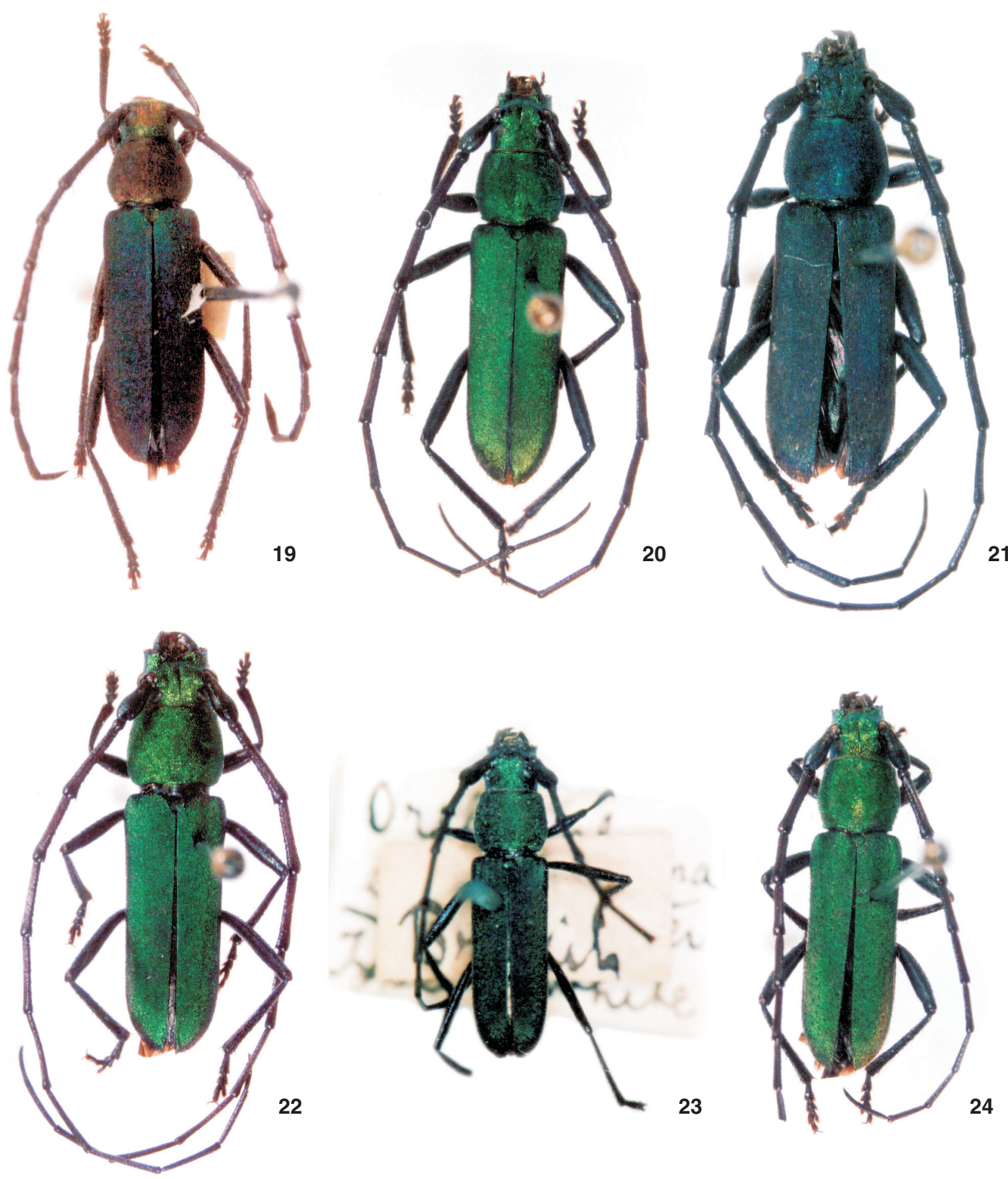

Figuras 19-24. (19) Aglaoschema collorata, parátipo fêmea, comprimento 9,7 mm; (20) A. apixara sp. nov., parátipo macho de EncruziIhada, Bahia, comprimento 14,2 mm; (21) A. concolor, macho de Rio Verde, Mato Grosso, comprimento 10,7 mm; (22) A. rufiventre, macho de Linhares, Espírito Santo, comprimento 11,7 mm; (23) Orthostoma erythrogaster, holótipo macho (BMNH), reproduzida de diapositivo; (24) Aglaoschema haemorrhoidale, macho do Rio de Janeiro, Rio de Janeiro, comprimento 10,8 mm. 
9,8-10,7; comprimento do protórax 1,8-2,5/1,7-2,0; maior largura do protórax 2,2-3,0/2,2-2,7; comprimento do élitro 6,78,8/7,2-7,7; largura umeral 2,5-3,3/2,5-3,2.

Material-tipo. Holótipo macho do BrasiL, Espírito Santo: Baixo Guandu, 23-31.XII.1970, C. T. \& C. Elias leg. (DZUP). Parátipos. BRASIL, Bahia: Encruzilhada (Estrada Rio-Bahia, km 965, Motel da Divisa, 960 m), 2 machos, fêmea, XI.1974, Seabra \& Roppa leg. (MNRJ). Minas Gerais: Cambuquira, macho, 7.XI.1968, H. Ebert leg. (DZUP); Viçosa, macho, 15.XI.1955, macho, XI.1955, E. Amante leg., fêmea (Luz), II.1948, F. Vanetti leg. (MZSP).

Discussão. A. apixara sp. nov. é semelhante a A. rufiventre, A. haemorrhoidale e $A$. concolor, especialmente à primeira pelas antenas do macho e forma do corpo mais alongada. Diferencia-se de $A$. rufiventre pela pontuação sexual grossa no prosterno, lados do protórax e do pronoto dos machos, pelos fêmures com pontuação fina e pubescência esbranquiçada, densas e pelos urosternitos I-II com colorido metálico. Em A. rufiventre (Fig. 22) o protórax dos machos tem pontuação sexual fina pouco conspícua e restrita ao prosterno; os fêmures têm pontuação e pubescência esparsas e todos os urosternitos são vermelhoalaranjados. Distingue-se de A. haemorrhoidale pelos élitros sem pontos ásperos, pelo antenômero XI, nos machos, um terço mais longo que o III, além do colorido metálico dos urosternitos I-II e da forma do corpo mais alongada. Em A. haemorrhoidale (Fig. 24), os élitros têm pontos ásperos aparentes em toda a superfície, o antenômero XI é mais curto que o III, os urosternitos são vermelho-alaranjados e o corpo é, proporcionalmente, mais curto. De A. concolor (Fig. 21), a nova espécie distingue-se pelos caracteres fornecidos na chave.

Etimologia. Tupi: apixara = semelhante, idêntico, alusivo à semelhança com $A$. rufiventre.

\section{Aglaoschema concolor (Gounelle, 1911)}

\section{Fig. 21}

Orthoschema (Orthoschema) concolor Gounelle, 1911: 177. Orthostoma concolor; Monné, 1993: 21 (cat.).

Aglaoschema concolor; Napp, 1994: 659; Monné, 2005: 118 (cat.).

Macho. Colorido metálico opaco, azul-escuro a verde, os élitros concolores ou não com o protórax; em alguns exemplares o disco dos urosternitos II-V castanhos. Antenas e pernas negras a castanhas.

Cabeça brilhante, pontuado-corrugada, com pubescência castanho-avermelhada pouco aparente. Mandíbulas como na figura 30: com dente externo rombo no terço apical; face externa sem depressão, grosseiramente pontuado-rugosa; face dorsal convexa com pontos grossos e irregulares. Escapo piriforme, pouco mais curto que metade do comprimento do antenômero III; depressão basal rasa; opaco, com pontuação áspera e densa em toda a superfície. Antenômeros III-V sulcados, brilhantes, subglabros, com pontuação fina, esparsa e áspera, e cerdas negras muito esparsas na face inferior dos III-IV; antenômeros distais pubescentes; XI tão longo quanto o III. Protórax bem transverso e amplamente arredondado nos lados, até tão largo quanto os úmeros, a maior largura no meio; margem anterior com largura subigual à posterior, os ângulos látero-posteriores não projetados. Pronoto densamente microcorrugado, a pubescência pouco aparente. Lados do protórax pubescentes, finamente corrugados. Prosterno com pontos moderadamente finos, densos a corrugados, sem pontos grossos entremeados; pubescência esbranquiçada densa. Meso- e metasterno microcorrugados, opacos com pubescência esbranquiçada pouco aparente. Élitros com pontos setígeros aparentes no disco e cerdas curtas mais numerosas para os ápices; extremidades arredondadas com o ângulo sutural inerme ou pouco projetado. Fêmures subopacos, com pontos finos, densos a corrugados e pontos setígeros, ásperos com cerdas castanho-avermelhadas aparentes; pubescência esbranquiçada aparente. Urosternitos, nas regiões com colorido metálico, microcorrugados com abundante pubescência esbranquiçada.

Fêmea. Escapo com depressão basal mais marcada do que no macho; antenômeros III-XI com pontuação e pubescência densas e espículos menos manifestos do que no macho, exceto os espinhos apicais externos dos VII-X, bem desenvolvidos; IXXI não encurtados e sem escova de cerdas; XI subigual à metade do comprimento do III. Protórax mais expandido e arredondado nos lados, com pontuação menos corrugada do que no macho; prosterno com pontos não corrugados e pubescência esparsa.

Dimensões, macho/fêmea respectivamente. Comprimento total 13,0-9,1/11,7-9,2; comprimento do protórax 2,5-1,8/ 2,2-1,7; maior largura do protórax 3,2-2,3/3,0-2,2; comprimento do élitro 8,8-6,3/8,5-6,5; largura umeral 3,3-2,3/3,3-2,5.

Material-tipo. De acordo com GounelLe (1911: 177), a série sintípica compõe-se de 10 machos e 8 fêmeas provenientes do BRASIL, Goiás: Jataí. Foram examinados quatro síntipos, dois machos e duas fêmeas (MNHN, Coleção Gounelle).

Discussão. A. concolor é semelhante a $A$. rufiventre e $A$. haemorrhoidale, particularmente os exemplares com colorido verde-metálico. Distingue-se de ambas pelo colorido dos urosternitos: inteiramente azul-escuro-metálicos ou, pelo menos, os I(II) e os demais com colorido metálico nas regiões laterais e castanho-escuros no disco; em $A$. rufiventre e $A$. haemorrhoidale os urosternitos são vermelho-alaranjados.

De $A$. rufiventre (Fig. 22) distingue-se, ainda, pelo escapo pouco estreitado na base com depressão basal rasa e pontuação áspera em toda a superfície; pelo protórax bem expandido nos lados, até tão largo quanto os úmeros, pelos élitros com pontos setígeros aparentes e pelos fêmures com pontuação e pubescência densas. Em A. rufiventre: escapo piriforme, com depressão basal profunda e sem pontos ásperos; protórax pouco alargado nos lados, élitros com pontos setígeros pouco conspícuos e fêmures com pontuação e pubescência esparsas; as fêmeas distinguem-se, principalmente, pelos urosternitos vermelhoalaranjados e pela depressão basal do escapo rasa (manifesta nas fêmeas de $A$. concolor).

De A. haemorrhoidale (Fig. 24), pela pontuação áspera do escapo, pelo antenômero XI tão longo quanto o III, pela pontuação sexual dos machos formada por pontos finos, pouco apa- 
rentes e pelos élitros sem pontos ásperos. Em A. haemorrhoidale a pontuação do escapo é fina; o antenômero XI é cerca de um terço mais curto que o III nos machos e mais curto que metade do comprimento do III nas fêmeas; os machos têm pontuação sexual formada por pontos grossos e profundos, entremeados com a pontuação fina, no prosterno e lados do protórax e os élitros têm pontos ásperos em toda a superfície.

Material examinado. Brasil, Mato Grosso: macho, XI.1927, 3 machos, XI.1929 (MZSP); Rio Taguarussu, fêmea, XI.1939, Dr. Nick leg. (MZSP); Rio Verde, 3 machos, 2 fêmeas, XI.1964, macho, XII.1966, A. Maller leg. (DZUP); Três Lagoas (Fazenda Beija-Flor), macho, X.1964, Exp. Dpto. Zool. leg. (MZSP). Mato Grosso do Sul: Rio Caraguatá ( $21^{\circ} 48^{\prime} \mathrm{S} 52^{\circ} 27^{\prime} \mathrm{W}, 400$ m), fêmea, II.1954, F. Plaumann leg. (DZUP). Goiás: Goiânia, macho, XI.1937, R. Spitz leg. (MZSP); Rio Verde, macho, 2 fêmeas, XI.1945, W. Zikán leg. (MZSP), 2 fêmeas, Dirings. leg. (MZSP), macho, fêmea, XII.1945 (MNRJ); Vianópolis, fêmea, XI.1931, R. Spitz leg. (MZSP), fêmea (Ponte Funda), X.1966, N. Tangerini leg. (DZUP). Minas Gerais: Água Suja, fêmea, X.1918 (MZSP); Pouso Alegre, fêmea, VI.1965, Vulcano \& Pereira leg. (MZSP). São Paulo: Ribeirão Preto (Faculdade de Medicina), 2 machos, fêmea, XI.1954, 4 machos, fêmea, XII.1954, M. P. Barreto leg. (MZSP); São Paulo, macho, 3 fêmeas, XII.1926, R. Spitz leg. (MZSP); São Sebastião, macho, IX.1915 (MZSP); Taquaritinga, fêmea, XII.1969 (MZSP). Paraguai: fêmea, F. Schade leg. (MZSP).

\section{Aglaoschema rufiventre (Germar, 1824)}

\section{Fig. 22}

Callichroma rufiventre Germar, 1824: 495.

Chrysoprasis rufiventris; Audinet-Serville, 1834: 7

Orthostoma rufiventre; Germar in Guérin-Méneville, 1839: 330. Orthoschema rufiventre; Aurivillius, 1910: 157.

Aglaoschema rufiventre; Napp, 1994: 659; Monné, 2005: 120 (cat.). Orthostoma erythrogaster White, 1853: 146. Syn. nov.

Orthoschema erythrogaster; Aurivillius, 1910: 157.

Aglaoschema erythrogaster; Napp, 1994: 659; Monné, 2005: 119 (cat.).

Macho. Tegumento com colorido verde ou azulado-metálico, subopaco, o protórax, freqüentemente mais claro que os élitros. Antenas e pernas negras a castanhas. Urosternitos vermelho-alaranjados.

Cabeça brilhante, densamente microcorrugada com pubescência esparsa. Mandíbulas como na figura 30: com dente rombo no terço apical; face dorsal convexa com pontos moderadamente grossos; face lateral não deprimida, grosseiramente pontuado-rugosa. Escapo piriforme, quase tão longo quanto metade do comprimento do antenômero III; depressão basal larga e profunda; opaco, com pontuação fina a moderada, mais densa até corrugada na base, e pubescência pouco aparente. Antenômeros III-V com pontuação áspera e cerdas esparsas na face inferior; pubescência progressivamente adensada para os antenômeros distais; XI tão ou pouco mais longo que o III. Protórax pouco arredondado nos lados, a maior largura no meio; margens anterior e posterior com larguras subiguais, os ângulos látero-posteriores não projetados. Pronoto e lados do protórax microcorrugados; pubescência inaparente e raras cerdas laterais. Prosterno microcorrugado, a pontuação sexual fina quase inaparente; pubescência esbranquiçada esparsa. Meso- e metasterno opacos, com pubescência esbranquiçada pouco aparente. Élitros com pubescência mais aparente do que no protórax; pontos setígeros não contrastantes, com cerdas curtas, pouco aparentes exceto próximo aos ápices; extremidades, usualmente, com estreito entalhe e projetadas junto à sutura. Fêmures brilhantes, com pontos finos, moderadamente profundos e densos, nos posteriores mais irregulares até corrugados; pubescência quase nula e cerdas castanho-avermelhadas esparsas. Urosternitos brilhantes, subglabros.

Fêmea. Escapo com depressão basal rasa, às vezes, pouco aparente; antenômeros com pubescência e pontuação mais abundantes do que no macho; IX-XI não encurtados e sem escova de cerdas; XI pouco mais longo que metade do comprimento do III; III-IV, às vezes, até inermes nos ápices. Protórax mais alargado com a maior largura após o meio; pronoto mais convexo com pontuação menos corrugada e mais alveolada e pubescência avermelhada mais aparente do que no macho; prosterno fracamente corrugado com pubescência esparsa.

Dimensões, macho/fêmea respectivamente. Comprimento total 16,7-10,3/17,0-9,7; comprimento do protórax 3,3-2,0/ 3,0-1,7; maior largura do protórax 4,0-2,3/4,0-2,2; comprimento do élitro 11,7-7,3/12,5-7,0; largura umeral 4,5-2,8/4,7-2,5.

Material-tipo. De Callichroma rufiventre Germar, 1824 (ZSMC). Não examinado. GERMAR (1824) não especificou o número ou sexo dos exemplares estudados e mencionou apenas "Brasilia" como procedência. De Orthostoma erythrogaster White, 1853: holótipo macho (Fig. 23) (BMNH), examinado, porta as seguintes etiquetas: 1) Brazil; 2) Orthostoma erythrogaster White; Type; 3) Orthostoma erythrogaster. O exame do holótipo permitiu propor a presente sinonímia.

Discussão. Aglaoschema rufiventre assemelha-se a A. apixara sp. nov., A. concolor e A. haemorrhoidale. De A. haemorrhoidale (Fig. 24) difere pelos caracteres mencionados na chave. Os caracteres que distinguem $A$. rufiventre de $A$. apixara e de $A$. concolor foram discutidos à pagina 812 .

Material-examinado. Brasıl, Paraíba: João Pessoa, fêmea, VII.1955, P. Pereira leg. (MZSP). Goiás: Campinas, fêmea, Schwarzmaier leg. (MZSP). Bahia: Condeúba, 2 machos, fêmea, II.1976, S. Souza leg. (DZUP); Encruzilhada (Estrada Rio-Bahia, km 965, Motel da Divisa, 960 m), macho, XI.1972, Seabra \& Roppa leg. (MNRJ). Minas Gerais: Viçosa: fêmea, XII.1948, F. Vanetti leg., macho, XI.1955, macho, II.1956, macho, IX.1956, fêmea, X.1958, macho, fêmea, XI.1958, E. Amante leg. (MZSP). Espírito Santo: Baixo Guandú, fêmea, XI.1964, macho, I.1971, macho, fêmea, XII.1971, T. Elias leg. (MZSP), fêmea, XII.1970, macho, X.1971, 2 machos, XII.1971, C. Elias leg. (DZUP); Barra de São Francisco (Córrego do Itá), macho, XI-XII.1956, W. Zikán leg. (MNRJ), 2 machos, 2 fêmeas, XI.1956, W. Zikán leg. (MZSP); Barra Seca (Córrego dos 
Menezes), fêmea, XII.1971, J. M. Lima leg. (DZUP); Conceição da Barra, fêmea, V.1968, C. T. Elias (DZUP); Itapina, macho, XII.1967, C. Elias leg. (DZUP); Linhares, fêmea, XI.1965, A. Maller leg., fêmea, XII.1972, C. Elias leg. (DZUP), 4 machos, 3 fêmeas, XII.1972, C. Elias leg. (MZSP), macho, I.1973, C. Elias leg., fêmea, X.1976, Enoqui leg. (DZUP), (Parque Sooretama) 3 machos, 4 fêmeas, XI.1967, F. M. Oliveira leg. (DZUP); Pedro Carneiro, fêmea, XI.1976, Enoqui leg. (DZUP); Santa Teresa, macho, fêmea, III.1964, C. Elias leg. (DZUP); São Mateus, fêmea, XII.1969, J. M. Lima (DZUP). Rio de Janeiro: Itaguai, macho, fêmea, II.1970, fêmea, XII.1970, W. Zikán leg. (MZSP); Seropédica, macho, XII.1946, dois machos, fêmea, W. Zikán leg., macho IV.1951, J. F. Zikán leg. (MZSP); Rio de Janeiro (Corcovado), macho, IV.1960, fêmea, XI.1962, fêmea, XII.1966, fêmea, I.1969, Alvarenga \& Seabra leg. (DZUP), fêmea, X.1962, Alvarenga \& Seabra leg., fêmea, X.1968, S. Fragoso leg., macho, 2 fêmeas, X.1975, 2 machos, XI.1975, M. A. Monné \& C. A. Campos Seabra leg. (MNRJ); fêmea (Floresta da Tijuca), V.1963, P. San Martín (MNRJ), fêmea (Manguinhos), IV.1953, R. Barth (DZUP), 3 machos (Represa Rio Grande), XI.1966, F. Oliveira leg. (DZUP), fêmea (Urca), V.1961, B. Reichardt leg. (MZSP). São Paulo: Itu (Fazenda Pau d'Alho), fêmea, XI.1973, M. A. Monné (MZSP); Monte Alegre (Fazenda Santa Maria, 1100 m), fêmea, XI.1942, F. Lane leg. (MZSP);; São Bernardo, macho, II.1926 (MZSP); São Paulo, (Saúde) fêmea, XI.1920, (Aclimação) fêmea, II.1923, (Morumbi) macho, III.1945, Dr. Nick leg., (Interlagos) fêmea, XII.1972, M. Carrera leg., (Santo Amaro) fêmea, XII.1941, Dr. Nick leg. (MZSP); São Sebastião, macho, IX.1915, fêmea, X.1920, fêmea, VIII.1924, Barbiellini leg. (MZSP). Paraná: Castro (Carambeí), 2 fêmeas, I.1971, Moure, Marinoni \& Giacomel leg., 2 fêmeas (Acácia), VI.1971, Marinoni leg., macho, fêmea, XII.1971, D. S. Napp leg. (DZUP); Curitiba, 3 machos, 6 fêmeas (Aroeira), XI.1967-I.1968, Dept. Zoo. leg., macho, I.1968, A. Sakakibara leg. (DZUP); Guarapuava, 2 machos, I.1972, Mielke \& Tangerini leg. (DZUP); Ponta Grossa, dois machos, 1942, macho, X.1943, fêmea, I.1945, F. Justus leg. (DZUP); Rio Negro, fêmea, I.1926 (MZSP); Rolândia, macho, XII.1953, Dirings leg. (MZSP). Santa Catarina: São Bento do Sul, 4 machos, fêmea, II.1974, C. Rank leg. (DZUP); Piçarras, macho, X.1975, L. Pereira leg. (DZUP).

Monné (2005) registra a espécie também para o Rio Grande do Sul (Brasil) e Misiones (Argentina).

\section{Aglaoschema haemorrhoidale (Germar, 1824)}

\section{Fig. 24}

Callichroma haemorrhoidalis Germar, 1824: 496.

Orthostoma haemorrhoidale; Germar in Guérin-Méneville, 1839: 330.

Chrysoprasis haemorroidalis; Burmeister, 1865: 169.

Orthoschema haemorrhoidale; Aurivillius, 1910: 157.

Aglaoschema haemorrhoidale; Napp, 1994: 659; Monné, 2005: 119 (cat.).

Macho. Tegumento subopaco, verde-metálico-claro. Antenas e pernas castanhas a castanho-avermelhadas. Urosternitos vermelho-alaranjados.
Cabeça brilhante, com pontuação fina e densa, corrugada na fronte, pubescência inaparente. Mandíbulas como em $A$. rufiventre, mas menos projetadas. Antenas ultrapassam o ápice elitral em 3,5-4,0 artículos. Escapo piriforme, quase tão longo quanto metade do comprimento do antenômero III; depressão basal larga e rasa; opaco, com pontuação fina e densa, um pouco áspera e corrugada na base; pubescência pouco aparente. Antenômeros III-V com pontuação um pouco áspera e algumas cerdas na face inferior; pubescência mais adensada para os artículos distais; XI cerca de um terço mais curto que o III. Protórax regularmente arredondado nos lados, a maior largura no meio; margens anterior e posterior com larguras subiguais, os ângulos látero-posteriores não projetados. Pronoto brilhante, densamente microcorrugado, com pubescência avermelhada pouco aparente e sem cerdas; aos lados com pontos grossos mais evidentes no terço anterior. Lados do protórax e prosterno microcorrugados com pontuação sexual formada por pontos grossos, mais profundos e densos no prosterno que é revestido por pubescência esbranquiçada densa e sedosa. Meso- e metasterno subopacos, com pubescência esbranquiçada aparente em toda a superfície. Élitros com pubescência mais aparente do que no pronoto; pontos setígeros contrastantes e ásperos, evidentes e uniformemente distribuídos em toda a superfície; cerdas curtas mais evidentes para as regiões laterais e ápices; extremidades arredondadas a subacuminadas, não entalhadas e não projetadas junto à sutura; não raro são mais afiladas e ultrapassam o ápice do abdômen. Fêmures com pontuação fina, densa a corrugada e pontos setígeros ásperos e contrastantes com cerdas castanho-avermelhadas; pubescência esbranquiçada bem aparente em toda a superfície. Urosternitos brilhantes, subglabros.

Fêmea. Escapo com depressão basal rasa, pontuação densa e pubescência bem aparente; antenômeros III-XI com pubescência e pilosidade mais abundantes do que no macho; VIII-XI mais evidentemente decrescentes, o XI pouco mais curto que metade do comprimento do III; IX-XI sem escova de cerdas. Lados do protórax e prosterno microcorrugados com pubescência esparsa.

Dimensões, macho/fêmea respectivamente. Comprimento total 14,2-8,8/14,2-9,3; comprimento do protórax 3,1-1,7/ 3,5-1,7; largura do protórax 3,5-2,0/3,8-2,3; comprimento do élitro 9,8-6,2/10,2-7,0; largura umeral 3,8-2,3/3,8-2,7.

Material-tipo. Não examinado. Germar (1824: 496), não indicou o número de exemplares estudados e mencionou apenas "Brasilia" como procedência. De acordo com Monné (2005) o material-tipo está depositado no ZSMC.

Material examinado. Brasil, Minas Gerais: Aimorés, 2 machos, XII.1970, C. Elias leg. (DZUP); Belo Horizonte, fêmea, O. Monte leg. (MZSP). Espírito Santo: Baixo Guandu, 14 machos, 3 fêmeas, XI.1970, macho, III.1971, C. Elias leg. (DZUP); Barra do São Francisco (Córrego do Itá), 11 machos, 8 fêmeas, XI.1956, W. Zikán leg. (MZSP), fêmea, XII.1956, W. Zikán (MNRJ); Linhares, fêmea XII.1972, C. Elias leg. (DZUP); Santa Teresa, fêmea, XI.1964, C. Elias leg. (DZUP). Rio de Janeiro: Rio de Janeiro (Corcovado), fêmea, XI.1961, Moure, Alvarenga \&

Revista Brasileira de Zoologia 24 (3): 793-816, setembro 2007 

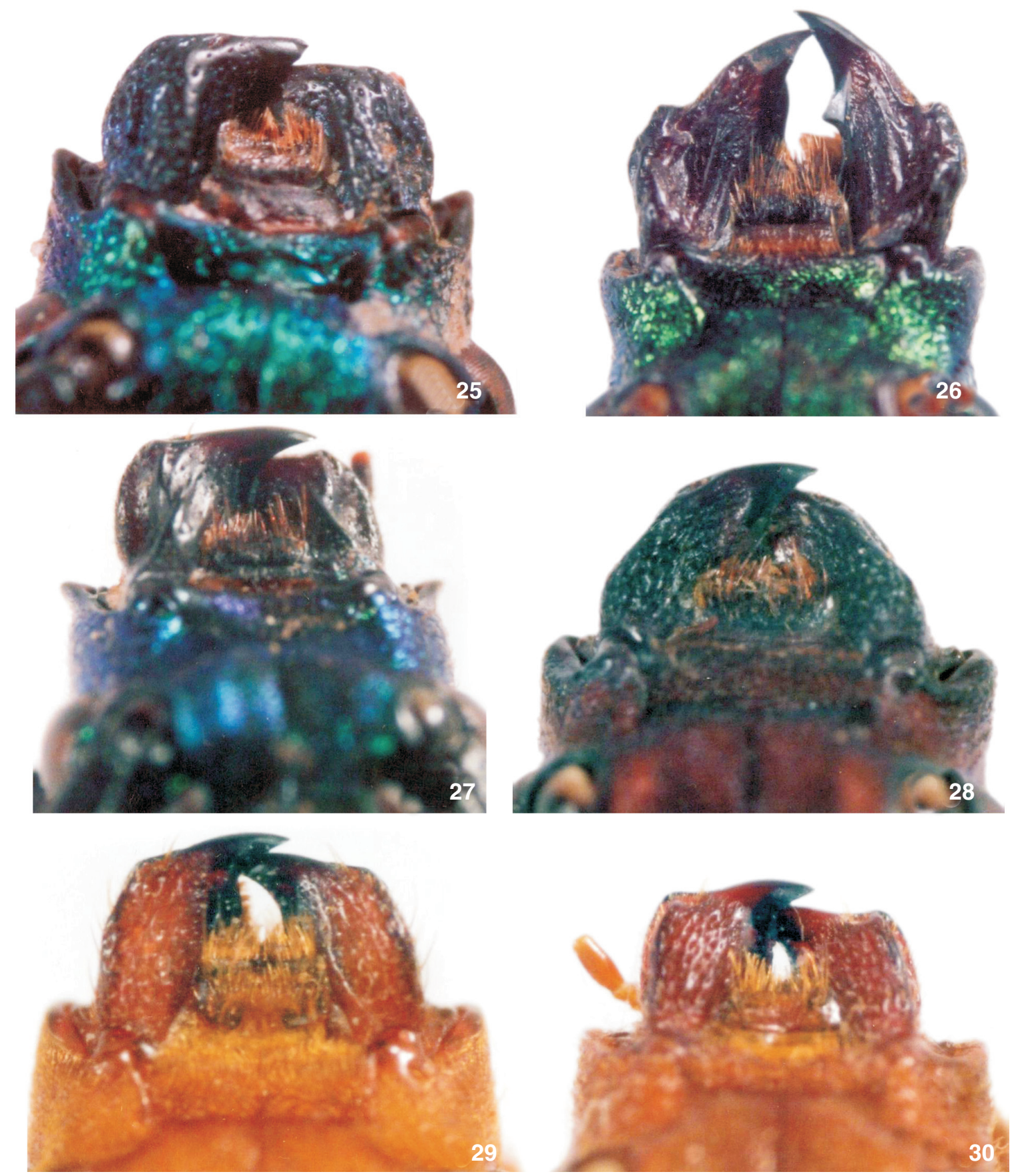

Figuras 25-30. Mandíbulas, macho. (25) Aglaoschema cyaneum; (26) A. ventrale; (27) A. tarnieri; (28) A. mourei; (29) A. viridipenne; (30) A. erythrocephla.

Seabra leg. (DZUP), 2 fêmeas, IX.1962, Alvarenga \& Seabra leg. (MNRJ), macho, fêmea, XII.1966, fêmea, X.1967, Moure \& Seabra leg., macho, fêmea, X.1970, Alvarenga \& Seabra leg. (DZUP), 3 machos, X.1975, 2 machos, fêmea, XI.1975, 3 machos, 2 fêmeas, X.1976, M.A. Monné \& C. A. Campos Seabra leg. (MNRJ), (Represa Rio Grande), macho, XI.1966, F.M. Oliveira leg. (DZUP). São Paulo: São Paulo (Saúde), macho, XII.1916 (MZSP); São Sebastião, macho, X.1927, Barbiellini leg. (MZSP). Monné (2005) registra a espécie também para Bahia, Paraná (Brasil), Misiones e Chaco (Argentina).

Revista Brasileira de Zoologia 24 (3): 793-816, setembro 2007 


\section{AGRADECIMENTOS}

Ao CNPq que propiciou recursos para estudo do material depositado no BMNH e MNHN; a Miguel A. Monné (MNRJ) e Ubirajara R. Martins (MZSP) pelo empréstimo de material para estudo e a Albino M. Sakakibara (DZUP) pelas fotos que ilustram o trabalho.

\section{REFERÊNCIAS BILIOGRÁFICAS}

Audinet-Serville, J.G. 1834. Nouvelle classification de la famille des longicornes. (suite). Annales de la Societé Entomologique de France (1) 3: 5-110.

Aurivillius, C. 1897. Neue oder wenig bekannte Coleoptera Longicornia. 5. Entomologisk Tidskrift 18: 241-248.

Aurivillius, C. 1910. Neue oder wenig bekannte Coleoptera Longicornia. 11. Arkiv för Zoologi 7 (3): 143-187.

Aurivillius, C. 1920. Neue oder wenig bekannte Coleoptera Longicornia. 17. Arkiv för Zoologi 13 (9): 361-403.

Bachmann, A.O. \& O.R. Di Iorio. 2002. Types and related specimens of Cerambycidae and Disteniidae (Coleoptera) in the Museo Argentino de Ciencias Naturales "Bernardino Rivadavia", Buenos Aires, Argentina. Revista del Museo Argentino de Ciencias Naturales, n. s., 41 (1): 55-93.

Bates, H.W. 1870. Contribution to an insect fauna of the Amazon Valley (Coleoptera: Cerambycidae). Transactions of the Entomological Society of London 1870: 391-444.

Burmeister, H.C. 1865. Longicornia Argentina. Systematische Uebersicht der Bockkäfer der La Plata-Staaten. Stettiner Entomologische Zeitung 26: 156-181.

Fabricius, J.C. 1801. Systema eleutheratorum secundum ordines, genera, species: adiectis synonymis, locis, observationibus, descriptionibus. Kiliae, Bibliopoli Academici Novi, vol. 2, p. 1-687.

Fuchs, E. 1959. Neue Cerambyciden (Coleoptera) aus dem Institut Royal des Sciences Naturelles de Belgique. Bulletin de l'Institut des Sciences Naturelles de Belgique 13 (35): 1-4.

Gemminger, M. \& E. Harold. 1872. Catalogus Coleopterorum hucusque descriptorum synonymicus et systematicus. Monachii, 9: 2669-2988.

Germar, E.F. 1824. Insectorum species novae aut minus cognitae, descriptionibus illustratae. Halae, Hendel \& Sons, XXIV+624p.

Germar, E. F. 1839. In: F.E. Guérin-Ménéville. Note synonymique sur les cérambycins décrits par M. Germar, dans son Insectorum species novae aut minus cognitae, descriptionibus illustratae, Halae, 1824. Magasin de Zoologie 1839: 329-331.

Gounelle, E. 1911. Liste des cérambycides de la région de Jatahy, Etat de Goyaz, Brésil. Annales de la Societé Entomologique de France 80: 103-252.

LACORDAire, J.T. 1869. Histoire Naturelle des Insectes. Genera des Coléoptères... Paris, Librairie Encyclopédique de Roret,
9 (1): 1-409.

LUCAS, P.H. 1857. Entomologie. In: Animaux nouveaux ou rares recueillis pendant l'expédition dans les parties centrales de l'Amérique du Sud, de Rio de Janeiro a Lima, et de Lima au Pará, exécutée par ordre du Gouvernement Français pendant les années 1843 a 1847, sous la direction du Comte F. de Castelnau. Paris, Bertrand, 204 p.

Melzer, J. 1933. Cerambycideos neotrópicos, novos ou pouco conhecidos. Revista de Entomologia 3 (3): 367-382.

Monné, M.A. 1993. Catalogue of the Cerambycidae (Coleoptera) of the Western Hemisphere. Part VIII. São Paulo, Sociedade Brasileira de Entomologia, 97p.

Monné, M.A. 2001. Catalogue of the Neotropical Cerambycidae (Coleoptera) with known host plant - Part I: Subfamily Cerambycinae, tribes Achrysonini to Elaphidiini. Publicações Avulsas do Museu Nacional 88: 1-108.

Monné, M.A. 2005. Catalogue of the Cerambycidae (Coleoptera) of the Neotropical region. Part I. Subfamily Cerambycinae. Zootaxa 946: 1-765.

Monné, M.A. \& E.F. Giesbert.1992. Nomenclatural notes on Western Hemisphere Cerambycidae (Coleoptera). Insecta Mundi 6 (2): 249-255.

NAPP, D.S. 1993. Duas espécies novas do gênero Orthoschema A.-Serville, 1834 (Coleoptera, Cerambycidae, Compsocerini). Revista Brasileira de Entomologia 37 (4): 653-656.

NAPP, D.S. 1994. Revisão do gênero Orthostoma Lepeletier \& A.Serville, 1830 e descrição de Aglaoschema, gen. n. (Coleoptera, Cerambycidae, Compsocerini). Revista Brasileira de Entomologia 38 (3-4): 645-660.

NAPp, D.S. \& U.R. Martins. 1988. Gêneros Euryprosopus White, 1853, Orthoschema Thomson, 1860 e Chaetosopus, gen. n.: sinonímias, novas espécies e nova combinação (Coleoptera, Cerambycidae). Revista Brasileira de Entomologia 32 (34): 479-486.

Napp, D.S. \& U.R. Martins. 2006. Notas e descrições de novos táxons em Cerambycinae neotropicais (Coleoptera, Cerambycidae). Papéis Avulsos de Zoologia 46 (4): 31-42.

PASCOE, F.P. 1860. Notices of new or little-known genera and species of Coleoptera. The Journal of Entomology 1: 36-64.

Prudhomme. 1906. Catalogue des coléoptères de la Guyane Française recueillis par M. Prudhomme de 1870 a 1906. Cayenne, Imprimerie du Gouvernement, 46p.

Thomson, J. 1860. Essai d'une classification de la famille des cérambycides et matériaux pour servir a une monographie de cette famille. Paris, Bouchard-Huzard, 396p.

White, A. 1853. Catalogue of the coleopterous insects in the collection of the British Museum. Longicornia 1. London, British Museum, 7: 1-174.

Zimsen, E. 1964. The type material of I. C. Fabricius. Copenhagen, Muuksgaard, 656p.

Recebido em 05.VI.2007; aceito em 20.VIII.2007.

Revista Brasileira de Zoologia 24 (3): 793-816, setembro 2007 